\title{
IV The Outer Circle of the Network: Friends of Business
}

Another circle of the Scolaris' social network in Hungary consisted of those individuals who established more distant links to the centre of the network - Pippo Scolari and his closest male relatives - but had no blood or marriage ties with them. Some of these men were neighbours to the Scolari and others were supporters of the Albizzi faction. But the most important features in their relations to the Scolari were their common business interests. John Padgett and Paul McLean claimed that company partnership may indicate existing friendship ties among individuals in this period. ${ }^{1}$ As we have already seen, the prevalence of the Medici faction which, according to Dale Kent, was built on networks of patronage, might have been closely related to their well-connectedness in business life. ${ }^{2}$ Following this argument, it might be safe to say that the Scolaris' success in the Kingdom of Hungary was also highly dependent upon their business network, which they built in both states. This web of relations in Hungary might have worked in a similar way to the patronage network of the Medici, facilitating the access to various city offices for their friends' friends. ${ }^{3}$

However, not all neighbours, political allies, and company partners necessarily became close friends to the extent that they might have wanted to cooperate with each other on other levels as well. For those who did, friendship most commonly included several other aspects too. Participation in legal matters is most commonly associated with strong friendship ties among Florentine individuals. Thomas Kuehn has widely investigated how neighbours, partners, and kin dealt with various sorts of disputes by means of private arbitrators. Given the importance of such mediation between individuals and their families, arbitrators were commonly chosen from their

1 'Florentines saw no contradiction between friendship and making money. Theirs was an instrumental conception of friendship. One purpose of helping each other was to make money [...] Amicizia language often escaled smoothly into the language of fictive kinship, which conveyed a sense of real loyalty.' Padgett and McLean, Economic Credit and Elite Transformation, p. 27.

2 Padgett and Ansell, 'Robust Action and the Rise of the Medici'. The existence of patronage ties inside the Medici faction is illustrated by the numerous letters of recommendations addressed to them. Kent, The Rise of the Medici, pp. 83-135.

3 McLean, The Art of the Network. 
closest relatives and friends. ${ }^{4}$ Similarly, the role of guarantor (fideiussor, mallevadore) in business disputes implied a close friendship tie with the beneficiary. Just as in the case of arbitrators and guarantors, witnesses and executors of documents had similarly important legal and private roles. These persons, therefore, should have been carefully selected among those acquaintances of the interested parties whom they trusted the most. ${ }^{5}$

In order to establish the circle of those businessmen in whom Pippo Scolari put his trust in business as well as in private matters, I have used the most important documents that concern the patrimony of the family. These sources include a document in which Pippo named the executors of Matteo's testament, the enforcement of Andrea's and Matteo's inheritances for Filippo di Rinieri Scolari and his brothers, and Pippo's deposit made for the painter, Masolino. These documents were issued in 1426, following Andrea's and Matteo's deaths, in which several Florentines who were important members of the resident Florentine community in Hungary were cited by name. Except for the last source, which was enacted thanks to an intermediary person who accepted Pippo's deposit in the first place, the other two documents are dated in Hungary. These acts, in my understanding, represent key moments in Pippo Scolari's life, in which he surely wished to rely on his most trustworthy friends.

The first source was issued on 25 March 1426, in Pippo's Buda house, in which he nominated the executors of Matteo's testament. Among them were Matteo's in-law, Vieri di Vieri Guadagni, their relative Simone di messer Andrea da Montebuoni, and three other Florentines: Bartolomeo di Giovanni Carducci, Pietro di messer Luigi Guicciardini, and Antonio di Pietro di Fronte. Furthermore, there were also four Florentine merchants living in the Kingdom of Hungary who were listed as witnesses of the document: Giovanni d'Andrea Lamberteschi, Gianozzo di Giovanni d'Amerigo Cavalcanti, Antonio di Bonaccorso Strozzi, and Nofri di Bardo de'Bardi. ${ }^{6}$

4 Kuehn, Law, Family and Women, pp. 19-74.

5 Kent has stressed the active role kinsmen played as executors of wills and as arbiters in disputes over property. Kent, Household and Lineage, 1977, p.132.

6 'Data in Buda con la presenza di domini Iohannes Andree de Lamberteschis, Gianozio Iohannis domini Emerici de Chavalcantibus, Anthonio Bonaccursi de Strozis, Iohannes Puccio

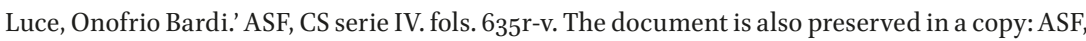
Corp. Rel. Sopp. 78. 326. fols. 296r-298v (with the wrong date: 05/03/1426), Published in short: Zsigmondkori oklevéltár, XIII. doc. 259. Another document connected to the same issue: Corp. Rel. Sopp. 78.326. fols. 292r-293r. (o7/03/1426) Published in short: Zsigmondkori oklevéltár, XIII. doc. 271. 
The second source is dated 26 August 1426 and testifies that via an intermediary, Pippo deposited a generous salary for Masolino, who was supposed to serve him for three years. The several guarantors of the execution of the commission included: the woodcarver-architect Manetto Amannatini, Nofri di Bardo de'Bardi, the Bishop Giovanni di Piero Melanesi, Simone di Lapo Corsi, Antonio di Piero Fronte, Ridolfo di Bonifazio Peruzzi, and Filippo di Simone Capponi, all of them important members of the Florentine community in Hungary. ${ }^{7}$

Months later, on 30 November 1426, in Brassov, Pippo reinforced the inheritance of Filippo di Rinieri Scolari and his brothers in the presence of Giovanni di messer Andrea da Montebuoni, Giovanni di Piero Melanesi, Currado di Piero Cardini, Lorenzo di messer Andrea da Montebuoni, Francesco di Vieri Guadagni, Giovanni d'Andrea Lamberteschi, Filippo d'Amerigo Frescobaldi, and Ricoldo di ser Paolo Ricoldi, and a certain Jacobo d'Antonio da Bologna. ${ }^{8}$

The performance of these Florentines might have contributed to Pippo's success in the Kingdom of Hungary to a remarkable extent. Only some of them served him in administrative positions, as it was customary in contemporary Hungary that barons placed their most able and trustworthy familiares in charge of their castles, territories, and anything they might have possessed or administered. In Pippo's case, Pál Engel has pointed out that he employed several of his wife's Hungarian relatives who were bound to him by feudal ties. ${ }^{9}$ Florentine businessmen who worked as officials or held ecclesiastical positions typically also made it into the Hungarian feudal structure and became Pippo's or Sigismund's familiares, or even both. Having possessed reading, writing, and arithmetic skills, these businessmen received employment in the royal or ecclesiastical administrations, thanks to Pippo's influence. These were the competencies which also led Pippo and other Italians into the royal administration, including, for example, the Saracino

7 Molho, 'The Brancacci Chapel', p. 93.

8 ASF, Diplomatico, Lunghe, Badia fiorentina, 30/11/1426. For the copy of the document see: ASF, Corp. Rel. Sopp. 78. 326. fols. 278r-279v. For the publication of the copy see: Zsigmondkori oklevéltár, XIII. doc.1432. There is very little evidence at our disposal on any further connections between Ricoldo and members of the Scolaris' network. Among them, appearing in Ricoldo's tax documents are Giovanni di Matteo Corsini and Giovanni di Rinieri Scolari, the first in the capacity of business partner. ASF, Catasto 62. fol. 561 r. 81. fols. 142v-143r. (1427) In his later declaration appear Costanza Scolari, sister of the Bishop of Varadinum, as well as Tommaso Corsi and Tommaso Davizi, silk manufacturers. ASF, Catasto 500. fol. 452r.

9 Engel, 'Ozorai Pipo', pp. 275-276. 
brothers from Padua, who made a notable career in Louis I's service; one of them was also later elected to consul of the Italian community in Buda. ${ }^{10}$

Among the witnesses of the document naming the executors of Matteo's testament was Nofri di Bardo de'Bardi, who also served as one of the guarantors of Masolino's payment. The Bardi was one of the most ancient and extended lineages of Florence. They were also magnates and lived in the Oltrarno. ${ }^{11}$ Among the families in this study, they had the far highest number of households (54) registered in the 1378 Estimo. Most of them, like Nofri's father, Bardo di Migiotto de'Bardi, lived in the gonfalon of Scala, quarter of Santo Spirito. ${ }^{12}$ By the end of our period, in 1433, the number of their households increased to 62 and included 269 family members all together. ${ }^{13}$ Given the high number of households, they also declared by far the highest total assets of 142,093 Florentine florins. Among the registered households, only seventeen, less than one-third, did not have any taxable assets and only one was listed as miserabile. ${ }^{14}$ The wealth of the lineage might have come mainly from their business. During the fourteenth century, several of them settled in various parts of Europe, including London, Barcelona, and Valencia. ${ }^{15}$

As for their earlier connections to Hungary, in 1400, one member of the lineage, named Benedetto, was collecting ecclesiastical taxes in Kalocsa in the name of Giovanni di Bicci de'Medici's firm. ${ }^{16}$ Another member of the lineage, named Antonio di Geri de'Bardi, appears as a minor partner in the company based in Hungary that was owned by Matteo Scolari, Tommaso Borghini, and Piero di Bernardo della Rena. ${ }^{17}$ In 1388 , there was also a certain

10 For the Saracino brothers' participation in the royal administration, see: Weisz, 'A szerémi és pécsi kamarák', pp. 39-46. Prajda, 'Justice in the Florentine Trading Community'.

11 Other branches of the lineage have been studied in detail by Christiane Klapisch-Zuber. Klapisch-Zuber, Retour à la cité. See also: Lansing, The Florentine Magnates, Appendix.

12 Four households were located in various other parts of the city. ASF, Estimo 268. fols. 51v, 59r, 11r-v. For Bardo's household see: ASF, Estimo 268. fol. 3r.

13 Most of them continued to live in the same gonfalon, though already thirteen households were located elsewhere in the city. ASF, Catasto 488. fols. 78v, 153r, 159r, 161v, 169v, 189r, 207r, 287v, 347r, 348v, 329r; Catasto 49o. fols. 66v, 174v, 331v, 437r; Catasto 491bis. fol. 294v.

14 Lorenzo di Leonardo di Francesco. ASF, Catasto 499. fol. 471r.

15 Soldani, Uomini d'affari, pp. 398-40o.

16 Esch, 'Bankiers der Kirche im Grossen Schisma', p. 375.

17 ASF, NA 5814. fol. 270r. 
Nofri di Francesco de'Bardi registered in the sources. He purchased a house in Buda and continued to live there even after 1390, the year he sold his property. ${ }^{18}$ Though the two Nofries were contemporaries, it might not be possible to tell if and how they were related to each other.

\section{Nofri di Bardo de'Bardi: The Royal Administrator (d. 1426) ${ }^{19}$}

By the late fourteenth century, the Bardi family and their companies had been operating in the Kingdom of England for more than a century, and they had also entered royal service. The research of Martin Allen has demonstrated that the central administration employed several Florentines through the fourteenth century. ${ }^{20}$ Among them was Walter (perhaps Gualtieri?) di Filippo de'Bardi, who, in 1380 was appointed to master of the London exchange; he also retained the administration of the London mint for the first time in history. Thanks to his various offices, between the 1360 and the 1390s royal minting was kept in his hands.

Parallel to the examples in the Kingdom of England, during Louis I's reign there were some Italians receiving employment in the royal administration. However, their number, especially of Florentines, increased considerably with Pippo Scolari's success in the court. Although these administrative positions did not come with real power, they offered Florentines a solid income and the chance to get acquainted with members of the court, which might have further facilitated their trade and integration in the country.

Nofri (Onofrio) di Bardo de'Bardi might have been a royal administrator like his distant relative, Walter. There is nothing known for certain about his life prior to his employment or how exactly he ended up in the Kingdom of Hungary. Some sources suggest that from his mother's side, he might have been related to the Buondelmonti family. ${ }^{21}$ Maybe this family connection led him to Pippo Scolari's service in the salt chambers. In 1409, eight years

18 Zsigmondkori oklevéltár, I. doc. 648. (12/07/1388) He sold his house to Miklós Kanizsai. Zsigmondkori oklevéltár, I. doc. 1379. (27/02/1390) He might have been one of Bardo di Francesco di messer Alessandro de'Bardi's brothers, who was employed in the Medici bank. Kent, The Rise of the Medici, p. 73. The close family connection is also supported by the frequent appearance of the Scolaris' relatives in Bardo's account book, dated to 1426. Among them; Vieri Guadagni and Piero di Bernardo della Rena. ASF, Libri di commercio e di famiglia 361. fols. 27v, 28v, $29 \mathrm{r}$. I thank Sergio Tognetti for calling my attention to the source.

19 Engel, Magyarország világi archontológiája.

20 Allen, 'Italians in English Mints', pp. 53-62. Ibid., Mints and Money.

21 A certain Bardo de'Bardi married Bartolomea di Lorenzo di messer Gherardo Buondelmonti. ASF, Diplomatico, Normali, Rinuccini, 16/07/1362. (Though the inventory includes a reference to the document, it might have been consequently lost.) In a balance, prepared after the Bishop's 
following the baron's nomination as count of the salt chambers, he would have already been a middle-aged man when the first source mentions him. ${ }^{22}$ Between 1413 and 1418 , he managed the Buda salt chamber as well as the Kremnica chamber, where Pippo began his career as a royal officer. ${ }^{23}$ More than a decade later, he was also granted the castle of Pölöske in Zala County. ${ }^{24}$ By this, Nofri became the owner of feudal lands with a noble title in Hungary and obtained the right to use the name of Pölöskei Noffry. In August 1426, the King conferred upon him also the administration of the thirtieth chamber, earlier occupied by another Italian. ${ }^{25}$ During his years in royal service, Nofri developed into a respected man in Buda, where he purchased a house in proximity to the court and benefited from the support of Pippo and the King. Nofri's influence in their service increased to the extent that following the baron's death, he and his four sons were trying to take over Pippo's position in the court and in the Florentine community too.

By the late 1420s, Bardo, Giacomo, Giovanni, and Leonardo di Nofri performed in various capacities for the King. ${ }^{26}$ In 1427 , Giovanni served as Sigismund's ambassador to Florence. ${ }^{27}$ Leonardo, between 1427 and 1435 , was relator in the royal court like his father. ${ }^{28} \mathrm{He}$ also handled Gianozzo di Giovanni Cavalcanti's case on Sigismund's behalf. The possible rivalry with the Scolari nephews led to the consolidation of the Bardis' social position in Hungary. Nofri, though, died sometime before 1430, but his sons seemingly had no major problem in maintaining their father's former offices and social status. In 1430, Sigismund granted the brothers the castle of Bojnice (SK) in exchange for Pölöske. ${ }^{29}$ In the same year, they took over the thirtieth chamber, which they administered at least until $1437 .^{30}$ In the same period, Giovanni and Leonardo served the King together as captains of the

death, Lorenzo Buondelmonti and Bardo de'Bardi figured together as Andrea Scolari's creditors. ASF, Corp. Rel. Sopp. 78. 326. fol. $260 v$.

22 Rinaldo degli Albizzi, who stayed in his Buda house, mentioned him as Pippo Scolari's former factor. Commissioni di Rinaldo degli Albizzi, III. p. 580. Zsigmondkori oklevéltár, II. 2. doc. 7240. (27/12/1409).

23 Zsigmondkori oklevéltár, IV. doc. 226. (25/02/1413); VI. doc. 47. (25/01/1417).

24 Engel, Magyarország világi archontológiája, I. 396.

25 Zsigmondkori oklevéltár, XIII. doc. 990. (19/08/1426).

26 Engel, Magyarország világi archontológiája, I. pp. 176, 271.

27 ASF, Signori, Legazioni e Commissarie 7. fol. $76 \mathrm{v}$.

28 ASF, Signori, Missive, I. Cancelleria, 32. fols. 52v-53r (12/03/1429), ASF, Corp. Rel. Sopp. 78. 326. fols. 235r, 262r-v. The same document: ASF, Miscellanea Repubblicana 10. Inserto 26o. I wish to thank Péter E. Kovács for calling my attention to the last document.

29 Engel, Magyarország világi archontológiája, I. p. 271.

30 MNL, DF 202473 (15/08/1430), DF 227547 (23/05/1437), DF 249985 (25/11/1432), DF $23955^{\circ}$ (13/10/1430), DF 286310 (23/05/1437). See also: Teke, 'Firenzei kereskedőtársaságok', p. 206. 
castle of Skalica (SK). ${ }^{31}$ In 1437, they were mentioned as counts of the royal chambers. ${ }^{32}$ The Bardi brothers had managed to consolidate their positions in the royal administration to the extent that they were able to remain in royal service even following Sigismund's death. ${ }^{33}$ The leading role gained by the Bardi brothers inside the resident Florentine community is clearly indicated by the brothers' election to Latin consul, sometime before $1431 .{ }^{34}$

In 1433, in the same year that we find Leonardo in Sigismund's entourage while visiting Siena, their paternal uncle, Migiotto di Bardo de'Bardi (b. 1378) declared only a few pieces of land and two houses in Florence..$^{35}$ But the document does not refer to any large-scale business activity that would suggest an economic cooperation between him and his nephews in Hungary. ${ }^{36}$

Administrative positions of these sorts came with other advantages as well, including access to deposits of salt, a commercial good in high demand on the domestic market. In 1431, the balance of Giovanni di messer Bartolomeo Panciatichi's firm in Hungary mentioned that Nofri di Bardo owed them 11801 florins for goods, for which he promised salt from Maramures (RO) in return. ${ }^{37}$ In the same year, the old balance of the company run by Antonio di Piero di Fronte and Pagolo di Berto Carnesecchi in Buda listed Leonardo and Giovanni di Nofri as debtors, saying that they were protected by the King and, therefore, they could not be forced to pay. ${ }^{38}$ Following Pippo's death, given the Bardis' noble titles and positions in the

$3^{1} \quad$ Engel, Magyarország világi archontológiája, I. p. 419.

32 Engel, Magyarország világi archontológiája, II. p. 176.

33 In 1438, Leonardo was appointed to royal treasurer. Engel, Magyarország világi archontológiája, I. p. 53.

34 Both Leonardo and one of the former consuls, Giovanni Saracino, served the King as counts (comes) of the thirtieth chamber around the years of their election to consul which may or may not imply that there was a connection between the two offices. '[...] dominum Leonardum Nofrii Bardi de Florentia iudicum latinorum et egregio Hungarie et suos fratres et eorum sotios et societatem [...]'. ASF, Mercanzia 271. fol. 118v. (14/11/1436).' [...] Al nome di Dio a dì 2 di dicembre 1431. Già manifesto a qualunche persona vedrà o udirà la presente scripta come dinanzi a voi Sano degli Ugorgieri da Siena vice giudice de latini in luogo di messer Lionardo di messer Giovanni di Nofri da Boymoy [...]'. Mercanzia 4379. fol. 98v. (In reality, the document talks about the brothers, Leonardo and Giovanni di Nofri). See also: Mercanzia 4379. fols. 114V-115r. I wish to thank Lorenz Böninger for calling my attention to the documents.

35 Commissioni di Rinaldo degli Albizzi, III. pp. 551-552.

36 ASF, Catasto 432. fols. 162r-163v. Catasto 487. fols. 312r-314v.

37 However, the payment did not arrive. ASF, Catasto 381 . fol. $43 \mathrm{v}$.

38 ASF, Catasto 381. fol. 91r. Bardo di Nofri de'Bardi was a business client of the wool workshop run by Giovanni di Gualtieri Portinari and Jacopo d'Andrea de Pazzi. See Portinari's tax document, submitted in 1433. Catasto 482. fol. 615r. 
royal administration, they fully integrated into the Hungarian society, which gave them an extraordinary advantage when dealing with other Florentines or subjects of the Hungarian crown.

\section{$2 \quad$ The Melanesi (Milanesi) Family}

Like the Bardi, the Melanesi brothers - Giovanni, Simone, and Tommaso di Piero - were among the Scolaris' closest friends of those with whom they did not share any blood or marriage ties..$^{39}$ Giovanni himself appears both in Masolino's payment and in reinforcing the Scolari nephews' inheritance. Earlier, in January 1426, Simone witnessed Andrea Scolari's testament in the episcopal palace of Varadinum. ${ }^{40}$

The Melanesi (Milanesi) family originated in nearby Prato, which explains why we do not find their names in the 1378 city census. The brothers' uncles worked as merchants in their hometown. ${ }^{41}$ Meanwhile their other distant relatives joined the clergy, among them a certain Niccolò, who was probably their fourth brother. ${ }^{42}$ By the end of the studied period, four of their households were registered in various parts of the city in the 1433 Catasto. ${ }^{43}$ They had a modest total asset of 6165 Florentine florins; only one of them possessed taxable assets, and one was even listed as miserabile. ${ }^{44}$ The brothers' two uncles, Luigi di Ricovero and Melanese di Ridolfo, established business interests in the Kingdom, though it is not clear if these enterprises went back before Pippo Scolari's time. ${ }^{45}$ At the beginning, the Melanesi

39 For a genealogical tree, see: Prajda, 'Unions of Interest', Appendix.

40 ASF, Corp. Rel. Sopp. 78. 326. fol. $291 \mathrm{v}$.

41 Baldassare and his father Luigi di Ricovero kept a money-changing desk at the Mercato Nuovo. ASF, Catasto 474. fols. 289r-29ov. In 1408, Luigi also figures among Francesco di Marco Datini's business partners. Luigi's letter to Datini. AD, busta 1097. Inserto 18. (05/05/1408).

42 In 1390, Michele di Matteo was mentioned as clergyman. ASF, Diplomatico, Pergamene, Arte di Calimala, 23/04/139o. Nicholozo di Neri Melanesi, provost of Prato. ASF, Catasto 484. fol. 581r. (1433) In 1426, Niccolò was a protonotary apostolic. Archivio Segreto Vaticano, Obligationes et Solutiones 6o. fol. 157r. Published in short: Zsigmondkori oklevéltár XIII. doc. 504. Archivio Segreto Vaticano, Camera Apostolica, Obligationes Communes. fol. 121v. (27/04/1426)

43 Baldassare di Luigi. ASF, Catasto 498. fol. 65r. (golfalon Drago, quarter of San Giovanni); Matteo di Vanni. Catasto 497. fol. 522r. (gonfalon Leon d'Oro, quarter of San Giovanni); Filippo di Filippo. Catasto 496. fol. 193v, Tommaso. Catasto 496. fol. 499v. (gonfalon Leon Bianco, quarter of Santa Maria Novella).

44 Matteo di Vanni Melanesi's houshold was listed as miserabile.

45 One of their uncles, Luigi di Ricovero, kept a servant of Hungarian origins. 'Martino d'Ungheria mio famiglio'. ASF, Catasto 474. fols. 29ov. (1433). Meanwhile another, Melanese di Ridolfo, died in Hungary. See his sons' declaration in 1433, saying 'Il detto se n'andò in Ungheria 
might have entered into the Hungarian market thanks to their cooperation with the Portinari family, who, together with the Panciatichi, ran what was probably the oldest continusly operating firm in the region..$^{46}$

\section{Giovanni (d.1427), Simone (1387-1427/1431), and Tommaso di Piero Melanesi (1391/93- c. 1437): The Double Citizens of Florence and Buda}

Buda, as the financial and administrative centre of the Kingdom and place of the royal court, developed into the favorite destination for itinerant Florentine businessmen who even established a joint consulate there. Because of the city laws that prevented harsh competition between local and foreign merchants, becoming a citizen of Buda might have offered Florentine merchants with considerable advantages in long distance trade. Non-indigenous merchants were not allowed to engage in any commercial activity without the consent of the town court judges and the local merchant community, and once they arrived in Buda, they were required to sell their goods there. ${ }^{47}$ They were not allowed to have their own measurements or to sell their goods to other foreign merchants. It was strictly observed how much they bought or sold of different types of goods, including textiles and leather. ${ }^{48}$ The statutes also prohibited domestic merchants from forming partnerships with their foreign counterparts. ${ }^{49}$ In addition, Buda citizens were free everywhere in the Kingdom of Hungary from paying tolls, except the royal thirties.

The Melanesi brothers held dual citizenships; they still paid taxes in Florence, but at the same time they paid taxes in Buda, as local citizens..$^{50}$ Citizenship, for early Renaissance Florentine businessmen, was a key to success. Reinhold C. Mueller's studies on Venetian citizenship have revealed that during the studied period a significant number of Florentines received the right to trade under the Venetian flag. Dual citizenships might not have

e llà si morì.' ASF, Catasto 457. fol. 550v. (1433). This last source is not entirely clear; it may refer to Melanese's in-law, Piero di Gherardino as well.

46 In 1427, the Melanesi rented their house in Florence from the Portinari. 'Tegniamo una chasa a pigione nel gonfalone del vaio, da primo e secondo via, terzo Bernardo Portinari, quarto Folcho Portinari. La quale chasa è di Giovanni di Gualtieri Portinari al presente, avemola noi a pigione da Giovanni d'Anthonio Portinari [...]. ASF, Catatso 46. fol. 653v.

47 Buda város jogkönyve, pp. 348-349, articles 68, 69.

48 Buda város jogkönyve, pp. 352-354, articles 74-77.

49 Buda város jogkönyve, p. 360 , article 387.

50 See Simone Melanesi's Florentine tax return, submitted in 1427: 'E più à d'incaricho che pagha alla terra di Buda ogn'anno per la colta, cioè per la taglia come cittadino di Buda [...]'. ASF, Catasto 46. fol. $655 \mathrm{v}$. 
been rare; there are examples of a Florentine merchant family who paid taxes in both Florence and Venice. Among them, besides the Scolari nephews, the Gaddi and Zati families surely possessed citizenship and immovable properties in both places..$^{51}$ This, as we have seen in the Scolari nephews' case, facilitated their commercial enterprises remarkably.

The Melanesi brothers' attempt to set foot in Buda served a similar purpose. Their father, Piero di Filippo, was member of the Florentine Moneychangers' Guild, and around the turn of the century he formed a company with another businessman from Prato. ${ }^{52}$ At that time, their uncle, Filippo di Filippo (1363-1433), with whom Piero worked in close cooperation, maintained his businesses as well as his immovable properties in Prato. By 1382, Filippo and Piero appeared together as business partners in Francesco di Marco Datini's correspondence. ${ }^{53}$ Following their father's death, the Melanesi brothers remained closely linked financially to their uncle; they belonged to the same household and even paid taxes together in Florence. ${ }^{44}$

If their father and uncle had any business interests in Hungary like their other relatives, the sources do not tell us. The precise date of their arrival in the Kingdom of Hungary is also unknown. Simone, probably the eldest of the brothers, was documented for the first time in Buda in $1416 . .^{55}$ Back then he was working as an agent of Antonio di Piero di Fronte and Pagolo di Berto Carnesecchi's firm in Buda, which suggests an early relation to the Scolaris' business network. This helped him to find some stability in Buda where he married Lucia, the daughter of a local Buda citizen. ${ }^{6}$ To obtain citizenship in Buda, foreigners would have needed either immovable properties in the city or guarantors who would have ensured the payment of their taxes. ${ }^{57}$ Simone's marriage probably was designed as a way to facilitate his attempt to obtain citizenship. He rented his house, located in the Via dei Latini, from the heirs of a Venetian merchant, where he kept horses and servants like many well-off businessmen in Florence..$^{8}$

$5^{1}$ See for example Taddeo di Zanobi Gaddi's tax return, presented in 1427: ASF, Catasto 79. fol. 61ov. Giuliano, Niccolò and Uberto d'Amerigo Zati's tax return, in 1433: Catasto 452. fols. 897 r-9oir.

52 Niccolao di Marco da Prato ASF, Arte del Cambio 12. fol. 61v. (1401?).

53 Piero's and Filippo's letter to Datini. AD, busta 183. Inserto 24. (42/11/1382).

54 Their joint tax return, submitted in 1427: ASF, Catasto 46. fol. $649 \mathrm{r}$.

55 Nuti, 'Un mercante', pp. 1-5.

56 In 1427, Lucia was 22 years old. ASF, Catasto 46. fol. $655 \mathrm{v}$. In 1433, she was mentioned as 34 years old. Catasto 467 . fol. 5 12r.

57 Buda város jogkönyve, p. 346, article 66.

$5^{8}$ ' [... [ una casa a pigione posta in Buda nella Via de Latini, dalle rede di Daniello Cini da Vinegia, pagha l'anno fiorini 3o. E più tiene 6 famigli e 8 chavagli [...] E più à d'incaricho che 
In a similar way as their father and uncle, Simone and his brother Tommaso cooperated closely in business life both in Florence and in Hungary. 59 In April 1424, their uncle, Melanese di Ridolfo, who later died in Hungary, allowed them to use his movable and immovable properties for their commercial activity in the Kingdom. ${ }^{60}$ Seemingly the entire family, including their two uncles, Milanese and Filippo, put faith in their success, helping them with financial means to the extent that they were risking even their properties in Prato.

Tommaso, by following the already described social pattern, might not initially have had the intention to set foot in Buda. In contrast to Simone, he chose a Florentine girl for wife, the daughter of Luca del maestro Niccolò Falcucci. The marriage took place in 1425, probably years after Simone's wedding, and ensured them a further business connection to the Scolari, since Luca Falcucci's brother Giovanni traded as Andrea Scolari's agent in Hungary. ${ }^{61}$ By then, the Melanesi brothers set up their own business in Buda. The company, which was first mentioned in 1427, dealt with long-distance trade and offered safekeeping as well. Besides the Scolari, their business clients in Hungary included the Lamberteschi, Giovanni del maestro Niccolò Falcucci, and Antonio di Piero di Fronte, as well as several members of the court and Sigismund himself. Around the same date, the Melanesi brothers were operating a silk manufacturing firm with the Corsi brothers. ${ }^{62}$ Their firm even handled Masolino's payment on Pippo Scolari's behalf. ${ }^{63}$

Giovanni, the third Melanesi brother, was a clergyman. In 1424, we find him on Sigismund and Pippo's side in Hungary, witnessing the meetings of the imperial court. ${ }^{64}$ It is not clear if he had any previous appointments in Hungary, when on 22 April 1426, following Andrea Scolari's death, Martin V nominated him as Bishop of Varadinum. ${ }^{6}$ His brother, Tommaso, who

pagha alla terra di Buda ogn'anno per la colta cioè la taglia come cittadino di Buda l'uno anno per altro fiorini 6o.' ASF, Catasto 46. fol. $655 \mathrm{v}$.

59 ASF, Catasto 381. fols. 89r-v, 91r.

60 Bettarini, La comunità pratese, p. 234.

61 Priorista, p. 177. In 1427, Smeralda, according to the Melanesis' tax document, was 17 years old. ASF, Catasto 46. fol. 653v. In 1433, he mentiond his wife in the tax return. ASF, Catasto 467 . fol. 512r.

62 Tommaso became a member of the Por Santa Maria Guild. For the renewal of his membership see: ASF, Arte della Seta 7. fol. 188r. (1426).

63 Molho, 'The Brancaccia Chapel', pp. 93-94.

64 Regesta Imperii, XI. doc. 5894 (28/06/1424).

65 Archivio Segreto Vaticano, Registri Lateranensi 264. fols. 217v-218v. Published in short: Zsigmondkori oklevéltár, XIII. doc. 478.XV. századi pápák oklevelei, I. doc. 880. 
had kept contacts in the Apostolic Chamber, carried the papal bull from Rome. ${ }^{66}$ A letter written by Simone Corsi states that Giovanni was made bishop by virtue of Pippo Scolari ${ }^{67}$ However, Giovanni did not have the fortune to enjoy the incomes of the bishopric for long, and at the beginning of 1427 he had already been replaced by another clergyman. ${ }^{68}$ In fact, in 1431, their cousin Baldassare di Luigi Melanesi claimed that Simone and Tommaso had lost everything in Hungary because of Giovanni's premature death. ${ }^{69}$ In the meantime, Simone died too, leaving behind a child named Piero. ${ }^{70}$ Following these events, Tommaso settled in Buda with his family and lived in the household of his sister-in-law. By 1433, there was no way back to Florence for the Melanesi, since the Florentine commune took all their properties. ${ }^{71}$ Because of their severe business losses, their uncle Filippo di Filippo, as their guarantor, was even detained in prison in Prato. ${ }^{72}$

The family business collapsed in Florence and they had seemingly lost everything there. Tommaso found other means of income in Hungary. His constant travel between Italy and Hungary created a way to export silk textiles from their workshop as well as import copper to Italy.73 The first news about him engaging in copper trade goes back to 1429, when we receive information about a load of copper, in the value of 1000 Venetian

66 On 27 April 1426, Giovanni paid the servitium minutum to the Apostolic Chamber by his brother, Tommaso. Archivio Segreto Vaticano, Camera Apostolica, Obligationes et Solutiones 6o. fol. 157r, Camera Apostolica, Obligationes Communes fol. 3. 121r; Camera Apostolica, Obligationes Communes fol. 4. fol. 158v. Published in short: Zsigmondkori oklevéltár, XIII. docs. 504, 505.

67 'Tornò Tomaso Melanesi e portava la bolla del fratello cioè messer Giovanni che fatto veschovo di Varadino è andato in sino a Roma [...]'. ASF, CS serie I. 229. fols. 56 r-v. (11/04/1426) Published in short: Zsigmondkori oklevéltár, XIII. doc. 415.

68 Archivio Segreto Vaticano, Registri lateranensi 267. fols. 309r-311r. (11/07/1427) Published in short: XV. századi pápák oklevelei, I. 880. doc. 956. II. docs. 473-78.

69 'Ànno perduto ongni loro sustanza in Ungheria per la morte del veschovo, loro fratello.' ASF, Catasto 380 . fol. 269 r.

70 In 1427, Piero was four years old. ASF, Catasto 46. fol. 655 v. In 1433, he was ten years old. Catasto 467 . fol. 512 r.

71 In 1433, Andrea Lamberteschi wrote in his tax return that the Florentine commune took Simone's and Tommaso's properties. 'Tommaso e Simone Milanesi sono in Ungheria assi il commune preso i beni loro.' ASF, Catasto 445. fol. 81v.

72 In 1433, Filippo in his tax return wrote that '[...]Per non perdere la cittadinanza non darei questa iscritta di catasto perché le cinque degli acordi ànno venduti ogni nostri beni e sustanze per in nostri catasti e nulla me rimasò e per lo resto mi tenghono in prigione qui in Prato.' ASF, Catasto 466. fol. 394r.

73 Tommaso's frequent travels to Venice are also testified by the travel accounts of the ambassador, Luca di messer Maso degli Albizzi, who, on his way to Buda, met him in the port of Segna. ASF, Signori, Dieci di Balia, Otto di Pratica, Legazioni e Commissarie, Missive e Responsive 5. fol. $27 \mathrm{v}$. 
ducats, which he was supposed to ship to Giambonino di Rinieri Scolari in Venice. ${ }^{74}$ Tommaso was first mentioned as count of the copper chamber only in 1435, but at the time of the shipment he would have had access to copper deposits in Hungary. ${ }^{75}$ Since by 1425 both Simone and Tommaso had become Sigismund's familiares, we have no reason to doubt that they had already made their way into royal service. ${ }^{76}$ Tommaso served the King in official capacities, for instance, by carrying letters for him, and in 1431 he was dispatched to Florence as Sigismund's ambassador. ${ }^{77} \mathrm{He}$ died around 1436 as count of the Latheran Palace. ${ }^{7}$

\section{The Falcucci Family}

Among the witnesses of the document naming the executors of Manetto Scolari's testament were Giovanni del maestro Niccolò Falcucci, the Melanesi brothers' in-law. The Falcucci, like the Melanesi, were not of Florentine origins; rather, they came from Borgo San Lorenzo, a town of local interest, in the Florentine contado. It was maestro Niccolò di Francesco who decided to settle in Florence, and he built a notable career as one of the most respected doctors of his time..$^{79}$ In 1360 , we find him enrolled in the Doctors' Guild, and in 1378 he was among the tax payers of the parish of Santa Reparata, gonfalon Vipera, quarter of Santa Maria Novella.$^{80}$ However, his descendants do not appear in the 1433 Catasto, which might suggest that the family had died out or remained in Hungary. Maestro Niccolò's reputation was based on a single voluminous medical treatise, entitled the Sermones or Practica, which gained such fame that it was mentioned even in contemporary chronicles. ${ }^{81}$ Thanks to his medical practice, he was able

74 The correspondence between the Scolari brothers: ASF, Corp Rel. Sopp. 78. 326. fols. $367 \mathrm{r}$, 354v, 348r, 361r, 355r.

75 Draskóczy, 'Kamarai jövedelem', pp. 152-153.

76 Teke, ,Firenzei kereskedőtársaságok', p. 198.

77 In 1427 , the King sent messages from him to the ambassador, Piero di messer Luigi Guicciardini. ASF, Corp. Rel. Sopp. 78. 326. fol. 337r. See the Signoria's letter to Sigismund: '[...] Pro pace tractando atque habenda cum illustri domino duce Mediolano prout honorem Thomme Melanesi oratori vostro, nos factures executorus.' ASF, Signori, Missive, I Cancelleria, 33. fols. 61r. (6/o3/1431).

78 Regesta Imperii, XI. 2. doc. 11303. (20/03/1436).

79 Park, Doctors, p. 32 .

8 o Park, Doctors, p. 182, n. 95. ASF, Prestanze 369. fol. 67r.

81 Park, Doctors, pp. 133-134. In his tax declaration, Giovanni reported a copy of his father's book: 'Un libro fece maestro Niccolò, mio padre [...]. ASF, Catasto 53. fol. 1096v. 
to marry off at least three of his children into important merchant families, like the Corsini, for example. ${ }^{82}$ Falcucci, as a doctor of medicine, might have studied in Bologna, which may have given him the opportunity to meet Andrea Scolari or members of his circle. ${ }^{83}$ There were at least two doctors living in Andrea's court in Varadinum (Oradea, RO) who would have been familiar with Falcucci's work. ${ }^{84}$

\section{Giovanni del maestro Niccolò Falcucci (1379-a. 1433): The Agent of Precious Metals}

Like his brothers, Giovanni also married into a Florentine merchant family of little importance, taking as his wife the daughter of Giorgio d'Andrea di Tiello. ${ }^{85}$ Maybe his father's connections to Andrea Scolari's network helped him to establish contacts in Hungary. Doctors and merchants of precious metals (speziali) were traditionally enrolled in the same guild in Florence, which might explain in some way Giovanni's choice of a profession. He was already about forty years old, when, in 1419, we hear about him in Hungary for the first time. However, by then he might have been trading there for a while, mainly with silk and wool textiles. His business contacts included the Melanesi, the Corsi brothers, and Tommaso Borghini. ${ }^{86}$ A letter, written by Giovanni himself, alluded to the volume of his commerce. ${ }^{87}$ On one occasion,

82 Others married a Tolosini and a Raugi. Park, Doctors, p. 166.

83 Park, Doctors, p. 211.

84 The doctors, Geronimo da San Miniato and Alessandro di messer Antonio, were among the witnesses of Andrea's testament: ASF, Corp. Rel. Sopp. 78. 326. fol. $290 v$.

85 See Giovanni's declaration, submitted in 1427, in which he mentions his father in-law. At that time, his household included his wife, Nanna (aged 36 ), his daughter, Sandra (aged 14), Mona Lodovica, his niece (aged 30), and Bernardo di Matteo, probably his nephew (aged 23). ASF, Catasto 79. fol. 263r. Giorgio also refers to his son-in-law in his tax document. ASF, Catasto 297. fol. 110r.

86 'E più ò debitori e creditori in Ungheria e quali non vi posso dare perché non sono salde le ragioni [...]'. ASF, Catasto 53. fol. 1096v. His tax declaration submitted, in 1427: 'Debitori ed altre mercatantie [...] Panni mandati a Buda per le mani di Tommaso Melanesi furono otto panni de fecondi e de fini fi. 392 s. 11. Drappiera di seta dati a Melanesi, detti per mandare a Buda la somma di fi. 1020. Drapperia di seta dati a Giuliano Centinai, portati a Buda la somma di fi. 295 s. E più fe' dare Andrea Viviani portò a Buda drappi fi. 136 [...] Restami nelle mani di Melanesi di Buda cioè Simone e Tommaso a saldare conto di mie robe e di denari paghati [...]'. ASF, Catasto 53. fols. 1096r-v. 'Tommaso Borghini e chompagni per drappi auti fi.236 s. 10 [...] Tommaso Corsi e chompagni per promese fatte per me a più persone come disse Tommaso Melanesi per ragioni vecchie fi. 597 [...]'. Catasto 53. fol. 1097r.

87 ' [...] Sentito in quest'anno di più mercanatie mandate così a Lamberteschi atenenti a questa ragione che ogni dì mi rimanghono in debito di fiorini venti milia in fiorini xxv milia [...] e io sono 
the Lamberteschi brothers, Pippo's familiares, purchased goods from him in the value of 25,000 Florentine florins and remained indebted to him for 20,000 florins. His following letter, written from Hermannstadt, Transylvania (Sibiu, RO), seems to clarify that these high numbers were connected to the precious metal trade in which Giovanni was heavily involved. In that letter, Giovanni informed Andrea Scolari about marketing a piece of 18-carat gold, which was sold for 522 Florentine florins, 66 denari. Besides writing about his business success, he also encouraged the Bishop to send him more silver and gold that he might possess. ${ }^{88}$ Five years later, Giovanni was still staying in Hermannstadt, which indicates that he actually settled there. ${ }^{89}$

Transylvania, especially the region near Hermannstadt, was rich in salt and precious metals. Furthermore, the town, thanks to its German merchants, was well connected to other nearby and more distant markets as well. By the early fifteenth century, most precious metal deposits in Europe had already been exhausted. However, the Kingdom of Bohemia remained the most important source of silver, while the mines in the Kingdom of Hungary were the richest in gold and copper, though silver was found in considerable quantity there as well. Gold and silver processed in the Florentine mint and in the city's goldsmiths' workshops might have come from various locations, including the Iberian Peninsula, the Balkans, and north Africa. Until the 1405 occupation of Pisa, precious metals reached Florence mainly by Genoa and Venice. Paola Pinelli has shown that agents of Florentine businessmen, like Giuliano di Marco Marcovaldi from Prato, were responsible for shipments of silver from Ragusa to Florence and elsewhere..$^{90}$ Marcovaldi's correspondence, which covers the period between 1419 and 1434, seemingly testifies to the Signoria's claim that, 'Ragusan merchants (or those working in Ragusa) have filled up our commune with silver. ${ }^{91} \mathrm{King}$ Sigismund's orders prevented the exportation of copper and precious metals abroad; yet, Florentines working in the mining areas and in the minting chambers still managed to 'smuggle' them into Italy.

As we have seen, Giovanni's in-law, Tommaso di Piero Melanesi, was employed at least as early as the 1430 os in the administration of copper

qui in debito con questi cittadini con altri merchatanti di migliaia di fiorini e vogliono essere paghati non posso che non ò di che [...]'. ASF, Corp. Rel. Sopp. 78. 326. fols. 328r-v. (17/05/1419). 88 ' $[. .$.$] Mando a uno merchatante un pezzo d'oro di fiorini 522$ denari 66 [...] anchora se avete altro oro o argento lo potete arditamente mandare qui [...]'. ASF, Corp. Rel. Sopp. 78. 326. fol. 388r. (04/06/1419).

89 ASF, Corp. Rel. Sopp. 78. 326. fol. 277r. (09/08/1424).

90 Pinelli, 'Largento di Ragusa'. Pinelli, 'Giuliano di Marco da Prato'.

91 Guarnieri, 'Intorno alle relazioni commerciali marittime'. 
mines. He, along with Giovanni, obtained an interest also in the trade of gold, silver, and copper. In 1431, a certain Piero di Parigi affinatore, that is, a skilled worker whose job was to refine precious metals, claimed that he was employed by Tommaso Melanesi in Hungary. ${ }^{92}$ This alludes to the fact that Florentines imported processed precious metals into Italy. Besides them, other Florentine citizens, like Rinaldo di Dego Rinaldeschi da Prato (c. 1398-1442), were also working in the Melanesis' service in the copper mines. ${ }^{93}$ The affinatore also mentioned that by January 1431, Giovanni di messer Niccolò's business had already failed, years before Tommaso Melanesi's first mention as count of the copper mines. ${ }^{94}$

One of the final destinations of precious metals extracted in Hungary was Venice. There, Giovanni Falcucci's most important business contact was the Zati firm; he sold precious stones, goldsmiths' articles, and jewels for them. ${ }^{95}$ One of the Zati, named Antonio di Francesco, was appointed to count of the minting chamber in Sighisoara, a town nearby Hermannstadt. ${ }^{96}$ Another of Giovanni's contacts in Venice was the Gaddi-Borghini firm, which traded in precious metals and stones. Because of the shortage of precious metals in Italy, the Scolaris' network, which was involved in its extraction, administration, and trade in Hungary, was given an enormous advantage. They were present in the mines and chambers and on the scene of international transport as well. In this enterprise, they seemingly cooperated with a group of businessmen that originated in nearby Arezzo, probably

92 'E ò ne avere da Tomaso di Piero Melanesi da Prato che abita nelle parti d'Ungheria fiori venti cinque, i quali danari gli ò serviti in Ungheria, credo e ttengho mi sarà faticha esser paghato. fiorini 25.' ASF, Catasto 375. fol. 532r. (31/01/1430) I wish to thank Lorenz Böninger for calling my attention to the source. Four years later, in 1427, the 38 -year-old Piero did not refer to any activity in Hungary or that he was in any way connected to the Scolaris' network. ASF, Catasto 59. fol. 743r. Therefore, his employment likely took place sometimes between 1427 and 1431.

93 ASF, Catasto 47. fols. 522-523, Draskóczy, 'Kamarai jövedelem', p. 153. See his later tax declarations: Catasto 370. fol. $400 \mathrm{r}$ (1431); Catasto 467. fol. 363r. (1433). He returned from Hungary before 1442 , and according to his tax document, he was suffering from some illness. ASF, Catasto 621. fol. 472 r.

94 '[...]E ò ne avere da Giovanni del maestro Nicholo, ch'è falito e resto avere da lui fi. circha a quaranta. Non ò saldo il chonto. fiorini 40.' ASF, Catasto 375. fol. 532r.

95 See also the debtors' list of his declaration, submitted in 1427: 'E abbiamo nelle mani de Zati di Vinegia tre anelle e bocchette con rubinetti e altre pietre stimatemi 2 anni fa fi. mille. Ora perch' el tempo è peggiore come vedete, la ragiono fi. 800 d'oro, metete voi come vi pare, sono cose lunghe a finire [...]'. ASF, Catasto 53. fol. 1096v.

96 Draskóczy, 'Olaszok a középkori Erdélyben', p.126. Filippo Zati went with the king to England. Bárány, 'Zsigmond király 1416-os angliai kísérete', p. 8. 
headed by a local nobleman, named Mariotto di Biagio Griffolini. ${ }^{97} \mathrm{We}$ also find among them a certain Agnolo, citizen of Buda, who developed an interest in the precious metal trade..$^{8}$ However, given the unavailability of sources that would allow us statistical calculations, the volume of precious metal trade between the Kingdom of Hungary and the Italian Peninsula cannot be estimated.

\section{The Corsi Family}

Simone di Lapo Corsi was one of the guarantors of Masolino's payment, which the firm they kept with the Melanesi handled on Pippo Scolari's behalf. The Corsi were of popolani origins, and starting from 1367 its members were active participants in the meetings of the secret councils. ${ }^{99}$ Over the course of the century, they were also elected as priors several times. ${ }^{100} \mathrm{In}$ 1378, they had perhaps three to five active households in Florence located in the two distinct gonfalons of Ruote, quarter of Santa Croce and Leon d'Oro, quarter of San Giovanni. ${ }^{101}$ Back then, three members of the family were listed as retail cloth merchants. ${ }^{102}$ In 1433 , they had eight households, which counted 35 members. ${ }^{103}$ Four households declared 15,271 florins as total assets, but the other four did not have any taxable assets at all.

97 Black, Benedetto Accolti, p. 7. He also figured as debtor in the balance of the Buda company of Antonio di Piero di Fronte and Pagolo di Berto Carnesecchi: 'Marioto d'Arezzo e Biagio da Saghabria'. ASF, Catasto 381. fol. gov.

98 A Florentine company in Buda, in exchange for a business debt, received silver from a Hungarian baron which was taken to Agnolo's house to be weighed. This suggests that he had a trustworthy beam balance used for precious metals: '[...] si pesò il detto argento in casa d'Agnolo d'Arezzo, cittadino di Buda [...]'. ASF, Mercanzia 7120. fol. 254v. See Bernardo di Sandro Talani's declaration, submitted in 1433: '[...] Agnolo d'Arezzo dimora in Buda per retratto di suo rame [...]'. ASF, Catasto 45o. fol. 254v.

99 For further information about the family see: Preyer, Il Palazzo Corsi-Horne, pp. 33-35. 100 Bardo Corsi, silk manufacturer, and Francesco di Lapo, wool manufacturer, were elected several times as priors. Brucker, Florentine Politics and Society, p. 68.

101 Giovanni di Lapo. ASF, Prestanze 367. fol. 52r; Lapo di Francesco. Prestanze 367. fol. 53r; Domenico di Filippo. Prestanze 369 . fol. 15v; Also the heirs of Simone di Lapo were listed separately. Prestanze 367 . fol. $53 \mathrm{v}$. The other two households might not belong to the same family. Francesco Prestanze 369. fol.18v; Giusto. Prestanze 369. fol. 22 r.

102 Domenico and Giovanni di Filippo, who lived in the same household, and Francesco. ASF, Prestanze 369 . fols. 15v, $18 \mathrm{v}$.

103 Corso di Lapo. ASF, Catasto 491bis. fol. 133v; Simone di Lapo. Catasto 491bis. fol. 472r; Bartolo di Domenico. Catasto 492. fol. 85v; Matteo di Domenico. Catasto 492. fol. 346v; Niccolò di Francesco. Catasto 492. fol. 378r; Piero di Domenico. Catasto 492. fol. 415r; Benedetto di Niccolò. Catasto 497. fol. 16iv; Antonio di ser Bartolo. Catasto 496. fol. $38 \mathrm{v}$. 
The Corsi might be thought of as typical of those new men who made their name and fortune thanks to their participation in the early development of the domestic silk industry. By 1350, one member of the family was registered among the members of the Por Santa Maria Guild as a silk manufacturer. ${ }^{104}$ Another, Domenico di Francesco, from 1380 until his death in 1423-1424, kept a silk workshop in Florence, which was consequently taken over by his three sons. In the 1390s, he also appeared in Francesco di Marco Datini's account books as a silk manufacturer. ${ }^{105}$ In 1410, the two brothers, Domenico and Lapo di Francesco had two separate silk manufacturing companies. ${ }^{106}$ If they were connected to the Scolari earlier we do not know; they seemingly did not share marriage or neighbourhood ties with them.

\section{Simone (1389/139o-p. 1434) and Tommaso di Lapo Corsi (1383/1384- p. 1434): The Third Generation of Silk Manufacturers}

The early development of the Florentine silk industry, similar to the Venetian case, was characterized by the activity of a group of immigrant Lucchese manufacturers who, starting from 1314, brought their know-how into the city. ${ }^{107}$ By 1378 , there were 44 silk manufacturers (setaiuoli) and retail cloth merchants (ritagliatori) registered in the city census, which might indicate the development of the sector. ${ }^{108}$

However, among the actors of the industry, very few families had also acquired a family name until that point, so it is not easy to tell if some or any of these manufacturers represented a second generation in the silk business. Florence Edler de Roover, in her analysis of the beginnings of silk production, mentioned the Corsi, Banchi, Antinori, Del Benino, and Parenti families among those few that, by the end of the studied period, had already obtained generational experience in the sector. ${ }^{109}$

104 De Roover, L'arte della seta, pp. 14-15.

105 For the letters see as examples: AD, busta 1150. inserto 28. codice 10655. (29/01/1396); busta 983. inserto 2. codice 421504. (26/o9/1396); busta 487. inserto 35. Codice 302524 (26/12/1396).

106 AFL, 3339. fols. 18r, 16r. (libro di debitori e creditori of Lazzaro di Giovanni di Feo Bracci's Florentine firm).

107 Franceschi, 'I forestieri e l'industria della seta'.

108 ASF, Estimo 268. fols. 3r, 34v, 35v, 77r, 82r, 84v, 87r-v, 88r; Prestanze 367. fol. 5r; Prestanze 368. fols. 11r, 19r, 24v, 46v, 47r-v, 70v, 73v, 74r, 77r; Prestanze 369. fols. 2r, 3v, 4r, 8r-v, 17r-v, 18v, 19r, 22v, 24r, 34v, 38r-v, 40v, 59v, 68v, 73r, 83r, 86r, 128v.

109 She claimed that among those enrolled in the Por Santa Maria Guild between 1328 and $1400,40 \%$ were related to another member of the guild by family ties, even though many of them worked as retail cloth merchants and had nothing to do with silk manufacturing. Edler de Roover, L'Arte della Seta, pp.13-23. 
In fact, Lapo di Francesco Corsi's two sons belonged to the third generation in the industry. Simone, the youngest among the brothers, enrolled in the Por Santa Maria Guild in $1389 .{ }^{110} \mathrm{He}$ and his brother Tommaso set up a silk firm in 1411, which might have been identical to the one reported on their 1427 tax return. ${ }^{111}$ Their silk workshop back then was located in the Via Porta Santa Maria. The place itself, as in many cases, was a rental; only the usufruct was of the company. ${ }^{112}$ The shareholders included Tommaso Corsi with 400 florins of investment, Simone Corsi with 1500 florins, Tommaso Melanesi with 2326 florins, Tommaso Davizi with 1815 florins, and Lodovico di ser Viviano with 500 florins of investments. ${ }^{113}$ The major shareholders were, therefore, the Melanesi and Davizi, and the manufacturing work seemingly remained the Corsi brothers' competency. Their second firm, declared in 1433 and kept with Zanobi Lottieri and Niccolò Cambini, might have had a completely different profile. ${ }^{114}$

The business clients of the silk firm included Simone di messer Andrea da Montebuoni and Pippo Scolari. ${ }^{115}$ For instance, the latter ordered silk textiles for Andrea's and Matteo's funerals. ${ }^{116}$ The firm might have been among the most prestigious in Florence, which explains the presence of foreign workers in their workshop. In 1427, a certain Niccolò di Giovanni, silk weaver of Hungarian origins, was mentioned as working for the Corsi brothers. ${ }^{117}$ In the very same year, the ambassadors heading to Hungary

110 ASF, Arte di Por Santa Maria 28. fol. 1v.

111 Edler de Roover, L'arte della seta, p.15. In 1420, the firm included as partners: the two Corsi brothers and Lodovico di Piero Cavalcanti. AFL, 3340. fol. 146v.

112 The workshop itself was Betto di Giovanni Manzuoli's. See Simone's tax declaration, submitted in 1427: 'Una meza entratura della bottegha dove facciamo l'arte della seta in Porta Santa Maria, la quale bottegha è di Betto di Giovanni Manzuoli, che da primo via, secondo, terzo rede di Pagholo di Tadeo Tomaso, quarto Benvenuto d'Ugholino Michi. La quale meza entratura la metto nella nostra chompagnia per parte del mio chopo per stima di fiorini $25^{\circ}$, benché in verità a vendita non varebe tanto. Trovomi in sulla bottegha tra merchatantie e denari chorenti fiorini 1050, $\mathrm{i}$ queli sono per chonpimento del mio chorpo dovevo mettere per insino alla soma di fiorini 1500 [...]'. ASF, Catasto 29. fol. 631r.

113 'Tommaso Corsi proprio tra capitale e ghuadagno fiorini 400 s. 28 d. 3. Tommaso Melanesi proprio tra capitale e ghuadagno fiorini $2326 \mathrm{~s}$. $18 \mathrm{~d}$. 10. Tommaso Davizi proprio tra capitale e ghuadagno fiorini 1815 s. 8. d. 11. Simone Corsi proprio tra capitale e ghuadagno fiorini 851 s. 28 d.3. Lodovicho di ser Viviano questi stanno per corpo di Simone Corsi e sono dati a catasto in nome di detto Simone, fiorini 500.' ASF, Catasto 29. fol. 654r.

114 ASF, Catasto 447. fol. 584 r, The declaration of Michele di Jacopo Lottieri: Catasto 484 . fols. $495 \mathrm{v}-496 \mathrm{r}$.

115 ASF, Catasto 29. fols. 653 r-v.

116 Simone Corsi's letter to Lodovico di ser Viviano. ASF, CS serie I. 229. fol. 55r. (04/07/1426).

117 ' [...] Sustanze e incarichi di me, Nicholò di Giovanni d’Ungheria, tessitore di drappi di seta [...] Devo avere da Tommaso di Lapo Chorsi e chompagni per lavorio tesuto è venduto loro 
received the task of recommending several Florentines to the King's favour, among them Tommaso Corsi. ${ }^{118}$ If the two pieces of information are somehow related to each other, it is not easy to tell. However, since the silk weaver surely had no possibility of learning weaving in Hungary, we must presume that he was employed in the Corsi's workshop to learn his profession. He was 24 years old, and the only entry of income in his declaration shows that he was weaving heavy silk velvet exclusively for the Corsis and that he also employed an apprentice. Though there is no further supporting evidence on the Corsis' connections to the court, Sigismund frequently purchased Florentine silk textiles and the lack of payments of considerable size to Florentine merchants might have inspired the King to consider installing experts of silk manufacturing in his court. A few liturgical robes, datable to the first decades of the fifteenth century and made of Italian silk textiles, have survived in the northern part of the Kingdom of Hungary, like Košice, Zipser Kapitel (Spišská Kapitula), and Bartfeld (Bardejov, SK). ${ }^{119}$ These towns served as local religious or market centres; therefore, local clergymen might have obtained silk textiles either by purchasing them from Florentine tradesmen or, more plausibly, via donations by members of the court. The workshop of the Corsi brothers, already famous for their generational experience in silk manufacturing, might have represented the best original firm to set up a silk weaving workshop in the proximity of the royal court.

The Corsi brothers occasionally traveled to Hungary, but they always kept their family home in Florence where they were involved in politics on the Albizzis' side. Simone appears only once as a speaker in the registers of the Consulte e pratiche. But Tommaso, starting from 1420, appears ten times in the corresponding volumes. ${ }^{120}$ Because of their filo-Albizzi sentiments, the two Corsi were sent to exile after Cosimo de'Medici's return to the city.

\section{5 The Lamberteschi Family}

Giovanni di Andrea Lamberteschi emerged as one of the witnesses at Pippo's Buda house, when he named the executors of Matteo's testament. Earlier,

\footnotetext{
bottegha chome dichono aparire per loro libri. Uno telaio da tesere zetani velutati chon ogni sua apartenenza [...]'. ASF, Catasto 31. fol. 853r. Arany, 'A cipész, a céhszolga és a szővőmester'. 118 ASF, Signori, Legazioni e Commissarie 7. fol. 8ov.

119 Wetter and Sipos, 'Kasel aus Kaschau', pp. 630-632. Ibid., 'Kasel aus Zipser Kapitel', pp. 632-633. Ibid., 'Kasel aus Bartfeld', pp. 633-634.

120 Simone: ASF, CP 47. fol. 6or. (1427) Tommaso: CP vols. 44, 46, 49, 50. (1420-1433)
} 
one of his brothers, Piero, testified with his presence at the writing of Andrea Scolari's last will. Since 1398, Andrea Lamberteschi's family were also in-laws of the Del Bene family, when Filippo di Giovanni del Bene married Andrea's daughter, Lena.

Despite the fact that the Lamberteschi was not a new family in Florence, in 1378 we find only one household registered under Bernardo's name, in the gonfalon of Carro, quarter of Santa Croce. ${ }^{121}$ In 1433, they had two households, including twenty-three family members. ${ }^{122}$ Compared to the other households studied in the present volume, the total assets of the Lamberteschi were very high; they declared 41,349 Florentine florins and the two households paid 160 florins, 21 soldi, and 16 denari of tax. The heads of the two households, Bernardo di Lamberto and Andrea di Tommaso, were probably second cousins who, by the turn of the fifteenth century, had developed into the most significant actors in the Florentine wool industry.

\section{Giovanni (b.1382/83), Piero, Niccolò (b. c. 139o), and Vieri d'Andrea Lamberteschi (b. 1389/139o): The Anti-Ottoman Military Captains}

Andrea Lamberteschi had five sons. Among them, Giovanni, Niccolò, Piero, and Vieri, settled in the Kingdom of Hungary. ${ }^{123}$ His fifth son, Tommaso, remained in the paternal house, helping his father with the wool business. ${ }^{124}$ Andrea imported raw wool from Flanders and, after processing it in the workshop on the ground floor of his Florentine palace, exported finished cloth to various destinations. ${ }^{125}$ Until 1396, the workshop was registered under Leonardo and Arnoldo Arnoldi's names, but most likely Andrea was its senior partner. Andrea's company also kept a permanent agent in Venice, in the person of Giovanni di Cenni Ugolini, who might also have been a minor shareholder. ${ }^{126}$ Andrea shared business interests with a number of

121 ASF, Prestanze 367. fol. 3 v.

122 Andrea di Tommaso. ASF, Catasto 491. fol. 27v; Bernardo di Lamberto. Catasto 491. fol. 42r. There is another household registered under the name of Lamberteschi, that of ser Giocco di ser Goccio di ser Manfredi, but in my opinion, they were unrelated to the previously mentioned two households. Catasto 496. fol. 223v.

123 See Andrea's declaration, submitted in 1427: 'In Ungheria sono ii miei figliuoli, cioè Johanni e Nicolò. Giovanni d'anni xLv costui à moglie que non à figliuoli. Nicolò d'anni xxxvii, non à moglie.' ASF, Catasto 27. fol. 92v.

124 He was enrolled in the Wool Guild. ASF, Arte della Lana 25. fol. 46v. (1408).

125 ASF, Arte della Lana 325. fol. 82r. He sent also wool textiles to Alessandria on the first Florentine galley. ASF, Catasto 27. fol. 92r.

126 For the company between the Lamberteschi e Giovanni Ugolini see for example: ASF, Mercanzia 4366. fol. 273v. (25/10/1426), Mercanzia 4366. fol. 337r. (15/11/1426), Mercanzia 7117. 
merchants belonging to the Scolaris' network, like Jacopo di Bartolomeo da Calenzano, Antonio d Bonaccorso Strozzi's in-law, Andrea Scolari, and Simone and Tommaso Melanesi. ${ }^{127}$ Also his cousin Bernardo had two wool workshops-warehouses: one in Pisa and another in Florence. ${ }^{128} \mathrm{He}$ imported raw wool on the first Florentine galley directly from Flanders, employing his son as agent. ${ }^{129}$ Both Bernardo and Andrea regularly sent wool textiles to the Kingdom of Hungary. Bernardo used the services of the Melanesi firm in the distribution of his goods, but Andrea sold his high-quality wool cloth via one of his sons, Piero. After a certain point, Giovanni, Niccolò, and Piero seemingly became independent from their father by initiating their own business in Hungary in cooperation with Giovanni and Currado di Piero Cardini, the latter of whom served as the provost of Varadinum..$^{130}$ There are no references in the sources to the way the Lamberteschi brothers entered into royal service. By 1422, Piero was already connected to the court, as he offered to mediate between Sigismund and the humanist Poggio Bracciolini. ${ }^{131}$ By the first years of the 1420 s, the brothers were already serving the King in a military capacity.

The use of companies of adventure and mercenary captains, called condottieri, was a widespread phenomenon in the battlefields of north and central Italy. William Caferro has pointed out that these 'bands emphasized their corporate nature by referring to themselves $[. .$.$] as societies, the same term$ used by contemporary Italian businesses. ${ }^{132}$ According to him, the terminology and the sturcture of the companies stressed their strong entrepreneurial character, and the captains of such companies were similar to owners and shop managers of industrial firms, seeking profits in the highly speculative business of war. Taking into account Caferro's argument, it is not suprising

fol. 132r. ASV, Giudici di petizion, Sentenze a giustizia 21. fol. 104v (20/08/1411).

127 See Andrea's declaration, submitted in 1431: ASF, Catasto 348. fol. $35 \mathrm{r}$.

128 See Bernardo's declaration, in 1427: ASF, Catasto 27. fols. 202v- 203 r.

129 'Mandai Lamberto, mio figliuolo in sule ghalee andarono in Fiandra [...]'. ASF, Catasto 27. fol. $203 \mathrm{v}$.

130 In 1423, the two of them appear together several times in the account book of the silk manufacturers, Bartolomeo and Giulio di Vieri Guidi and Francesco di Niccolò di Buto. AOI, Estranei 193. fols. 29r, 3or, 31r. In 1422, Piero Lamberteschi witnessed a donation of Andrea Scolari to Currado Cardini. ASF, Corp. Rel. Sopp. 78. 326. fol. 334r. In 1414, Giovanni enrolled in the Florentine Wool Guild. ASF, Arte della Lana 25. fol. 24r. Tommaso and Giovanni also became members of the Merchants' Guild. Tommaso: ASF, Calimala 6. fol. 9v. (1407); Giovanni: Calimala 6. fol. 12v. (1409).

131 John XXIII took with him to Constance several humanists, among them Poggio Bracciolini and Leonardo Bruni, which offered them the opportunity to meet King Sigismund. Davies, 'Poggio Bracciolini as Rhetorician and Historian', p. 167.

132 Caferro, John Hawkwood, p. 67. 
that the sons of one of the most important wool entrepreneurs at the time became military captains in Sigismund of Luxembourg's service.

We do not know if the Lamberteschi ever received military training; it is very plausible that they learned the art of war on Pippo Scolari's side. The baron himself served the King as a military captain against the Hussites, the Venetians, as well as against the Ottomans. Other Florentines - like the Archbishop Da Montebuoni, the Bishops of Varadinum, Andrea Scolari, and Giovanni Melanesi - were obliged as members of the royal aula, to take part in Sigismund's anti-Ottoman campaigns. In fact, in 1427, the ambassador Piero Guicciardini mentions that the Archbishop Da Montebuoni was with Sigismund and the other barons in his camp, which was set up at the borders of the Kingdom while waiting for the Ottomans' attack. The sources are very scarce regarding these early conflicts with the Ottomans near Hungary. However, Pál Engel maintained that in the support of voivode Davan II, there were three military campaigns to Wallachia, in the years 1423, 1425, and 1426, all of which were headed by Pippo Scolari as captain-in-chief of the royal troops. ${ }^{133}$

Pippo, who might have acquired his military skills thanks to his distant uncles, relied on the assistance of his fellow Florentines on the battlefield. In 1424, we find Niccolò and Vieri Lamberteschi on his side at the Danube while he was organizing against the Ottomans. ${ }^{134}$ In 1426 , their third brother, Piero, might have lost his life while fighting against the Ottomans with Pippo. ${ }^{135}$ Following the Spano's death, Niccolò remained in royal service as a military captain. Piero Guicciardini, who was on his way to Sigismund, reported on 30 August 1427, that the King, accompanied by his barons, was staying in his camp in Barcs at the borders of Serbia. His entourage included several Florentines; among them were the Archbishop Da Montebuoni, Filippo di Giovanni del Bene, Leonardi di Nofri Bardi, Lorenzo di Rinieri Scolari, and Simone Melanesi. The King informed them of the outcome of his battle on the Danube against the Ottomans, in which he lost an island located in the lower Danube area, 5000 men, among them 2000 Latini, and 25 armed fuste, which is a narrow, light type of galley. His captain (colonello) and commissary (comesser) in the battle were Niccolò Lamberteschi and

133 Engel, 'Török veszély', p. 281. Engel, 'Ozorai Pipo', pp. 53-88. About the conflicts in 1428 see: Veszprémy,' King Sigismund of Luxemburg at Golubac'.

134 'Un valaccho venuto da Sangnia dire questa mattina chome messer lo Spano à tratto di là Viero e Niccolò Lamberteschi.' ASF, Corp. Rel. Sopp. 78. 326. fol. 277r. (9/8/1424).

135 See Bernardo Lamberteschi's tax return, submitted in 1427: 'Piero e Nicholò Lamberteschi. Morì Piero, rimane Nicholo atende i facti d'arme in servigio dello imperadore contro a turchi.' ASF, Catasto 27. fols. 204r. 
Gasparre de Colle, respectively. ${ }^{136}$ Because of the severe losses, Sigismund decided to punish Gasparre, while he left Niccolò at the head of his troops. However, days later, in September, Niccolò was also imprisoned by the King's order, and he was released only following Guicciardini's and the Venetian ambassadors' audiences. The King declared him innocent and Guasparre de Colle guilty. Guasparre was captured and 20,000 florins were sequestrated from him. But after a short period of freedom, probably in late October, the King newly ordered both Niccolò and Giovanni Lamberteschi's capture and confiscated everything from them.

The ambassador Guicciardini once again begged Sigismund for the Lamberteschis' release, but the King's answer was that he would prefer shooting them one by one. ${ }^{137}$ Following Guicciardini's request, Sigismund's men even captured Niccolò's servant, Gianozzo Cavalcanti. ${ }^{138}$ Niccolò and Giovanni's imprisonment lasted far longer this time, since we find them in prison in the summer of 1428 when the Florentine ambassador was still fighting for their freedom. In fact, a royal hearing took place at the square of the Buda castle, in front of some barons as well as the Florentine, Milanese, and Venetian ambassadors. Niccolò, with compelling testimony, accused Guasparre de Colle of the disaster of Sigismund's fleet. There is no information at our disposal on who should have been held responsible for the events. In any case, the King did not accept Niccolò's explanation. In February 1429, the

136 'L'omperadore si trovava ai confini di Rascia in sul Danubio a una villa che si chiama Barccia sotto Buda otto giornate e da Saghabria a Buda sei giornate e da Sagabria a Barccia giornate cinque [...] meser l'arcivescovo Da Montebuoni, per comandamento del re, andava a champo chome gli altri baroni [...] e giugnemo a dì 14 di questo una villa in sul Danubio alla fore della Sava che si chiama Zemelin (Zemun, RS) presso dove il re à due miglia latini [...] e se non fosse disaventura che avenne alla sua armata di Danubio della quale era chapitano Nicholò Lanberteschi le cose passavano con gran danno de turchi [...] e si trovato poi per tradimento d'un valacho e chativi provedimenti d'un chomesser de re che aveva nome Guasparre da Colle. Sono seguiti quegli inconvenienti e N. Lanberteschi rimane colonore suo, ringrazie del re e quegli altri siano puniti, perdendosi non dimeno 25 fuste armate di quelle s'usano in Danubio [...]'. Piero Guicciardini's letter to the Dieci di Balia. ASF, Signori, Dieci di Balia, Otto di Pratica,

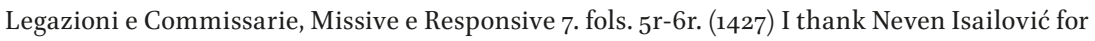
the identification of Zemun.

137 '[... Ier mattina solicitando disse volea principiare e a uno a uno sparargli di ragione, essendo sulla piazza del chastello, fece tirare fuori N. Lanberteschi e mandò l'ambasciadore viniziano que del ducha di Milano, messer Brunoro della Scala e me e alcuni baroni a udire quello didea Nicholò. Parveci volesse gravare Guasparre da Colle e così segnì che Nicholò non partendosi dal vero...e così parve a tuti d'acetare le sue scuse.' ASF, Signori, Dieci di Balia, Otto di Pratica, Legazioni e Commissarie, Missive e Responsive 7. fol. 19v. (14/07/1428).

138 '[... Per sue chagioni perduto l'Isola di Sagnia e xxv ghalea con vegogna e danno suo e v milla huomini [...]'. See another of Guicciardin's letters: ASF, Signori, Dieci di Balia, Otto di Pratica, Legazioni e Commissarie, Missive e Responsive 7. fol. 9 r. 
Florentine chancellery delivered an official letter to the royal court, asking Sigismund for the liberation of the Lamberteschi brothers. ${ }^{139}$ In April, a similar letter arrived at the royal court; both brothers remained imprisoned without any significant impact. ${ }^{140}$ In 1433, Andrea Lamberteschi claimed in his tax return that his sons were captured and robbed in Hungary by the King, and that they had already spent approximately seven years in prison. ${ }^{141}$ Even before that, the Lamberteschi brothers were considered unreliable businessmen by Giovanni Falcucci, so the charges against them might have had some foundation. However, their imprisonment was definitely related to the King's changed attitude toward members of the Florentine trading community, which characterized the period following the Spano's death.

\section{The Cardini Family}

Among the witnesses of Pippo Scolari's donation to the Scolari nephews was also Currado di Piero Cardini, back then provost of Varadinum. The Cardini would have been a completely new family in fourteenth century Florence, since there are no references to them among the Florentine office holders. ${ }^{142}$ In 1378 , they had only Giovanni's (named Freschetta) household registered in the Estimo, who lived in the gonfalon of Ferza, quarter of Santo Spirito. ${ }^{143}$ By 1433, Giovanni's sons, Antonio and Piero, formed two separate households, including ten family members, except Currado, who does not appear at all in the tax documents. ${ }^{144}$ The Cardini had 1229 florins of total assets, and none of them paid catasto, which shows their modest economic circumstances. They might not have had any earlier connection in Hungary, and their name did not appear among the Scolari relatives either.

139 'Supplicamus igita suprementie vostre ut de singulari dono gratie ac desolira liberalitate et celementia vostra Iohannes et Nicolaum de Lamberteschis liberare at as larger nobis dignetur.' ASF, Signori, Missive, I. Cancelleria 32. fols.178v-179r.

140 ASF, Signori, Missive, I. Cancelleria 32. fol. 65 r.

141 'In Ungheria rubato dal re e da certi altri singnori grande soma di denari a Giovanni e Nicolò, suoi figliuoli in prigione già sono più anni [...] Giovanni, figliuolo d'Andrea, anni 5o, Nicholò, figliuolo d'Andrea, annni 43; costoro sono in prigione in Ungheria; suti, presi e rubati da questo re e convienii di qui proevedere alia loro vita già è circha anni vii.' ASF, Catasto 445 . fols. 82r-v. 142 Online Tratte of Office Holders.

143 ASF, Estimo 268. fol. 55r.

144 Piero. ASF, Catasto 489. fol. 441r. Antonio. Catasto 498. fol. 49r. Currado's father was Piero di Currado Cardini. See Filippo di Rinieri Scolari's tax correction, submitted in 1431. Catasto 296. fol. 16or. 


\section{Currado di Piero Cardini (d. p.1439): The Trading Churchman}

Currado appears for the first time in Hungarian sources in 1418. Like other Florentine clergymen in Hungary - including Giovanni da Montebuoni, Carniano Scolari, Andrea Scolari, and Giovanni Melanesi - Currado, too, came from a merchant family. His father Piero died before the first general census and only a cousin, named Piero di Giovanni Cardini (c. 1377-p. 1433) remained in Florence; he was active as a wool manufacturer between 1406 and 1428. ${ }^{145}$ Currado's brother Giovanni worked as a merchant and developed business interests in Hungary and in Naples as well. ${ }^{146}$

Sources do not reveal anything about Currado's career as a churchman or his life prior to his first mention in 1418, as legate and collector of the tithe on Pope Martin V's behalf. ${ }^{147}$ As Tamás Fedeles has noted, he is the latest known example of a collector operating in Hungarian territory. ${ }^{148}$ Currado's activity is documented by several entries in the corresponding account book of the Apostolic Chamber, dated to 1421, in which he transferred the ecclesiastical revenues coming from different religious places in Hungary to the depositary, Bartolomeo de'Bardi. ${ }^{149}$ In the same year, he was also referred to as lector of the chapter of Varadinum (Oradea, RO). ${ }^{150}$ Currado might have been brought to Hungary by Andrea Scolari himself, who built a small court composed mainly of Florentines and Bolognese in his episcopal palace. In 1421, Currado was appointed the provost of Varadinum. ${ }^{15^{1}}$ However, a year later, in the presence of Piero Lamberteschi as witness, he agreed to transfer the incomes of his provost to the Bishop. ${ }^{15^{2}}$

145 ASF, Arte della Lana, 413. fol. 64v. (1406). He sentenced another Florentine at the consuls of the Wool Guild. ASF, Arte della Lana 329. fol. 12v. (1428).

146 In 1429, the Florentine Merchant Court addressed a letter to the Florentine consul in Naples in the case of Giovanni. ASF, Mercanzia 11313. (19/05/1429).

147 Zsigmondkori oklevéltár, VI. doc. 1797.

148 He made his vow as collector on 14 August 1419. Fedeles, 'Petrus Stephani collector', p. 37. 149 'Die xxiia mensis prefatiis dominus Antonius thesaurarius habuit recipiente dicto Bartholomeo de Bardis depositario nomine quo supra per manus domini Conradi canonici et lectoris ecclesie Varadiensis [...]'. Archivio Segreto Vaticano, Camera Apostolica, Introitus et exitus 379. fols. 6 or, $62 \mathrm{v}$.

150 In 1418, he was the lector of the chapter in Varadinum, papal legate and collector of the tithe in Hungary. Zsigmondkori oklevéltár, VI. docs. 2172, 2218. Archivio Segreto Vaticano, Obligationes et solutiones 58 . fol. $173 v$. (26/11/1420).

151 In 1421, he was already provost. XV. századi pápák oklevelei, I. doc. 429. See also the tax declaration of Currado's family, submitted in 1427: 'Messer Churrado è proposto di Varadino [...]'. ASF, Catasto 36 . fol. 239 r.

152 'Io Churado di Piero Cardini, preposto di Varadino fo manifesto per questa chome di ciò che monsignor messer Andrea, veschovo di Varadino avesse aministrato de frutti della prepositura 
The earliest information about his business activity is dated to 1423, when he and Andrea settled their balance with each other, which may in fact mark the dissolution of their business partnership. ${ }^{153}$ Their areas of operation included Hungary, Florence, and Rome, and the main profile of the firm was textile trade. In addition, Currado's continuous appearance as a papal collector suggests that their firm should have been involved in the international transfer of money as well. ${ }^{154}$

Despite their good connections to the Scolaris' network, the two Cardini seemingly did not successfully run their businesses in Hungary. In 1427, their stepmother, who prepared the tax return on their behalf, declared only a few parcels of land and some outstanding debt in Giovanni's name. ${ }^{155}$ In the same year, the two were among those Florentines who were captured and detained in the King's prison. ${ }^{156}$ The charges against them are unknown. In 1429, the Signoria recommended Currado to the King's favor, probably in the hope of his release. 157 Two years later, Giovani was still detained on the King's order. ${ }^{15}$ Following this news, in 1433, Currado petitioned the Pope to allow him to make his testament, which would indicate that his freedom had actually been restored. ${ }^{159}$ In fact, six years later, we find him again in the capacity of provost of Varadinum, which he probably retained until his death. ${ }^{160}$

Since the fourteenth century, Florentines in the papal court were engaged in banking activity as well as providing churchmen with commercial goods. Rome, at the end of the Great Schism, with the return of Pope Martin V

di Varadino, in detto mi chiamo qontento.' ASF, Corp. Re. Sopp. 78. 326. fol. 334r. (o2/o6/1422). 153 'Già manifesto a ciaschuna persona che legierà o vidirà a legiere la presente scritta chome messer Andrea Scholari veschovo di Varadino d'una parte e messer Churado Chardini preposto di Varadino dall'altra parte ambedue d'achordo ànno fatto ragione e salldo isieme di più diverse chose ànno avuto a ffare insieme chosì di danari chontanti chome di panni o d'altro o di promessi o pagamenti o chomessioni o lettere di chambio fatti l'uono all'altro o l'altro al uno [...] ne' reame d'Ungheria chome fuori de' reame in Italia o altrove, a Firenze, Roma o qualunque altro luogho [...]'. ASF, Corp. Rel. Sopp. 78. 326. fol. 332r.

154 XV. századi pápák oklevelei, II. doc. 657.

155 See the declaration of Nanna, widow of Piero di Currado Cardini and his step-sons. ASF, Catasto 37. fol. 997r. The brothers' joint declaration, submitted in 1427: 'Giovanni non à nulla se non debito chon diverse persone [...]'. ASF, Catasto 36. fol. 239r.

156 See the ambassador Piero Guicciardini's letter to the Signoria: ASF, Signori, Dieci di Balia, Otto di Pratica, Legazioni e Commissarie, Missive e Responsive 7. fol. 19v. (14/07/1428).

157 ASF, Signori, Missive, I. Cancelleria 32. fol. 65r. (07/04/1429).

158 Filippo di Rinieri Scolari wrote in his tax document 'Giovanni di Piero Cardini, il quale è preso in Ungaria [...]'. ASF, Catasto 385 . fol. 8 oor.

159 XV. századipápák oklevelei, II. doc. 298.

160 XV. századi pápák oklevelei, II. doc. 657. 
(1417-1431) to the city, attracted a considerable number of Florentine businessmen, studied mainly by Arnold Esch. Some of them, like Vieri Guadagni, were heavily involved in banking activity at the Apostolic Chamber. ${ }^{161}$ In Florence, St. Bernardino (1380-1444), from the Observant Franciscan order, had heavy influence on the ways Florentines related to trade and usury. ${ }^{162}$ He preached in 1417 and in 1424-1425 in Fiesole and Florence, and, later in his life, he dedicated an entire work to the subject. Bernardino took a stand in defending the work of businessmen and justified the social need for manufacturing and distributing commercial goods. ${ }^{163}$ However, the pattern observed in the case of Florentine-born Hungarian churchmen like Andrea Scolari and Currado Cardini, might not have been a widespread practice in the period. Besides the Hungarian examples, no other cases have come to light so far which would indicate that clerics of Florentine origins took part in local finance or in long-distance trade.

\section{$7 \quad$ The Capponi Family}

Filippo di Simone Capponi was also among the guarantors of Masolino's payment. As early as 1210, the Capponi, as an extended and ancient lineage, were listed as residents of the Oltrarno, and several of them were enrolled in one of the five major guilds of Florence. ${ }^{164}$ In 1378, the lineage had ten households, located mainly in the gonfalon of Nicchio, quarter of Santo Spirito. ${ }^{165}$ In 1433, the number of households increased to fourteen, comprising 73 family members who lived primarily in the same gonfalon. ${ }^{166}$ They

161 In 1422, the Cambini firm kept open branches in Florence and in Rome as well. Tognetti, Il banco Cambini, p. 34. For later examples, see: Weissen, 'Das deutsche Handesnetzwerk der Florentiner Banken'; Esch, 'Bankiers der Kirche im Grossen Schiasma.'

162 Goldthwaite, The Economy of Renaissance Florence, pp. 584-587.

163 De Roover, 'San Bernardino of Siena and Sant'Antonio of Florence'. On Bernardino as preacher see: Mormando, The Preacher's Demons.

164 Goldthwaite, Private Wealth, p. 187. The branch of Gino di Neri Capponi, studied by Goldthwaite, was one of the most important in Florentine business and politics.

165 Agostino di Neri. ASF, Estimo 268. fol. 76r; Capponcerio di Michozo. Estimo 268. fol. 76r; Sandro di Berto. Estimo 268. fol. 76r; Filippo di Tecco. Estimo 268. fol. 76r; Manetto di Mico. Estimo 268. fol. 76r; Andrea di Cappone. Estimo 268. fol. 76v; Giovanni d'Agnolo. Estimo 268. fol. $76 \mathrm{v}$; Bartolomeo di Cappone. Estimo 268. fol. 82r; Bonaccorso di Cappone. Estimo 268. fol. 82r; Nanni di Cappone? Prestanze 368.fol. 55v.

166 Agostino di Gino. ASF, Catasto 488. No folio number; Bastiano di Bastiano. Catasto 488 . fol. $78 \mathrm{v}$; Giovanni di messer Andrea. Catasto 488. fol. 153r; Giovanni di Sandro. Catasto 488. fol. 159r; Giovanni di Mico. Catasto 488. fols. 161v, 169v; Giovanni di Piero di Agnolo. Catasto 488. fol. 189r; Jacopo d'Agostino. Catasto 488. fol. 207r; Neri di Gino. Catasto 488. fol. 287v; Lorenzo 
declared 34,732 florins of total assets, and paid 60 florins, 94 soldi, and 55 denari of tax. There were four households among them that did not possess any taxable assets, and a fifth was listed as miserabile. ${ }^{167}$

Before Filippo's arrival to the Kingdom of Hungary, Filippo's brother Andrea was appointed as prior of Vrana, in the Kingdom of Croatia. ${ }^{168}$ In 1408, the Florentine government had dispatched an official letter to Pippo Scolari on his behalf, asking him to help Andrea in entering into his office. ${ }^{169}$ Andrea previously lived in Rome as a member of the Congregation of the Hermits of St. John the Baptist, which suggests a connection to the Apostolic Curia.

Simone di Filippo, their father, is regarded as one of the most important politicians of the early Albizzi period, having been involved in diplomacy as well. ${ }^{10}$ In 1412, he and Antonio di Fronte were in charge of mediating between Sigismund and Ladislaus of Durazzo, in the name of the Signoria. ${ }^{171}$ In 1404, Simone was sued by Matteo di Scelto Tinghi, a merchant who had been working for decades in the Kingdom of Hungary. ${ }^{172}$ Simone and Matteo might have been either partners in a business firm or important clients to each other, which indicates that Simone had already established business ties in the Kingdom. In 1390, as Standardbearers, they took part together in

di Gino. Catasto 489. fol. 329r; Bartolomeo di Piero. Catasto 490. fol. 66v; Giovanni di Piero. Catasto 490. fol. 174v; Nicola di Piero. Catasto 49o. fol. 331v; Zanobi di Niccolò. Catasto 49o. fol. 437r; Jacopo di Leonardo. Catasto 491bis. fol. 294v. In addition, there were two households that included only the heirs. Among them, one was registered under the name of Filippo di Simone's heirs. Catasto 488 . fol. $348 \mathrm{v}$.

167 The household of Jacopo di Lionardo. ASF, Catasto 491bis. c. $294 \mathrm{v}$.

168 In 1406, Andrea nominated his brother Recco di Simone as procurator. Esch, 'Florentiner in Rom um 140o', p. 498.

169 ASF, Signori, Missive, I. Cancelleria 25. fol. 3v. Another letter of recommendation on Andrea's behalf was sent by the Signoria to the King. Signori, Missive, I. Cancelleria 25. fol. 4r. He probably never entered into office since his name was not mentioned in Hungarian sources. He might also be identical with Andrea di Cappone Capponi, who in 1378 was registered as a resident of the gonfalon of Nicchio, quarter of Santo Spirito. ASF, Estimo 268. fol. $76 \mathrm{v}$.

170 He gave about 126 speeches at the secret councils: ASF, CP vols. 18-40. (1380-1409). Goldthwaite, in his book, did not discuss the branch of Simone.

171 Zsigmondkori oklevéltár, III. docs. 2468. (23/07/1412), 2536. (13/08/1412).

172 Matteo Tinghi sued Lorenzo and Simone Capponi at the consuls of the Wool Guild which might allude either to a partnership or to a close cooperation between them. 'Io Matteo dello Scelto mi richiamo delle rede e beni posessori di Lorenzo di Filippo Capponi e di Simone di Filippo Capponi [...]'. ASF, Arte della Lana 38. fol. 5r. (1404) Years earlier, in 1375, at the beginnings of the conflicts between Florence and the Papacy, Matteo Tinghi and his apprentice, Bonaccorso Pitti, were accused of spying in Avignon and were thrown in the papal prison. Trexler, The Spiritual Power, p. 39. 
the political discussions at the secret councils regarding Naples and King Charles. ${ }^{173}$

\section{Filippo di Simone Capponi (1367/68-c. 1431): 174 The Junior Partner of the Earliest Florentine Firm in Buda}

Maybe it was Andrea, or maybe it was their father, Simone, who helped Filippo build contacts in the Kingdom of Hungary. Filippo did not inherit his father's interest in politics; his name never appears among the speakers of the secret councils, or among the consuls of the major guilds and the Merchant Court. He might have been living in the Kingdom of Hungary for quite some time before he was mentioned for the first time in Hungarian sources. In 1412, when the Florentine chancellery dispatched a letter to him and Fronte di Piero Fronte in Hungary, Filippo was already in his forties. ${ }^{175}$ Filippo and Fronte were probably bound together by in-law ties, which would explain their close cooperation in business. ${ }^{176}$ In 1418 , the two of them were operating together in the Kingdom as collectors of papal revenues for Martin V. ${ }^{177}$ At that time, Filippo was employed as agent of the Panciatichi of Buda, the earliest Florentine firm found so far that was established in the city.

The Panciatichi were nobles, originally from Pistoia. The founder of the lineage left the city as an exiled Ghibelline in 1281 and made a fortune in service to the French king. ${ }^{178}$ The family, who were closely associated with Rinaldo degli Albizzi by marriage, had been trading in the Kingdom of Hungary for several decades. ${ }^{179}$ By 1387 , Gabriello di messer Bartolomeo, Florence's third richest citizen, had been selling wool textiles via his agent,

173 ASF, CP 28.

174 The date of his death was stipulated on the basis of the Tratte. Online Tratte of Office Holders, n. 37831 .

175 ASF, Signori, Missive, I. Cancelleria 29. fol. 26r.

176 Niccolò di Marco Benvenuti and Fronte di Piero deposited money for the furms of Pagolo Carnesecchi and Giovanni Panciatichi. ASF, Mercanzia 11778. fol. 31r. Fronte appeared as guarantor for Recco, Filippo's brother. See the declaration of Giovanni di Bartolomeo Panciatichi. ASF, Catasto 79. fol. 13or. In 1429, Giovanni di messer Bartolomeo Panciatichi sued the heirs of Antonio di Piero di Fronte for Venetian ducates, which in 1414 he promised to pay through Recco di Simone Capponi. ASF, Mercanzia 7117. fols. 340v-341v.

177 In 1418, Pope Martin V commanded the Archbishop of Esztergom to pay a certain sum to Filippo di Simone Capponi and Fronte di Piero Fronte. Zsigmondkori oklevéltár, VI. doc. 1483.

178 Herlihy, Medieval and Renaissance Pistoia, p. 167.

179 In 1420, Rinaldo degli Albizzi's son Maso married one of the daughters of messer Bandino Panciatichi of Pistoia. Kent, The Rise of the Medici, p. 179. 
Maruccio di Pagolo Marucci, in Zagreb. ${ }^{180}$ His nephew Antonio di Giovanni also merchandized cloth on a regular basis in Buda, by other merchants and maybe by his own local branch. ${ }^{181}$

In the last decades of the fourteenth century, the Panciatichi firm in Buda probably grew into the most significant local Florentine firm. The senior partner, Giovanni di messer Bartolomeo Panciatichi (1356- $p$. 1431), was one of the wealthiest citizens in Florence, and he ran another merchant firm with Giovanni di Gualtieri Portinari in Venice. ${ }^{182}$ Part of the success of the Buda branch was due to Filippo Capponi's presence; he likely lived there for more than two decades. ${ }^{183}$ Thanks to the marriage between Giovanni Panciatichi and Filippo's sister, the two of them became brothers-in-law. ${ }^{184}$ Employing in-laws at the head of a merchant-bank or its branches was still not a rare practice, which is clearly exemplified by the organization of the Medici Bank. Bartolomeo di Bartolomeo Bardi (1397-1429), manager of the Rome branch, Ilarione Lipaccio Bardi (1379-1433), general manager of the Medici bank, and Giovanni d'Adoardo Portinati (1363-1436), branch manager in Venice, were all bound to the Medici by marriage ties. ${ }^{185}$ The Panciatichi's intention to keep the firm in the hands of its family members

180 'Dinanzi a voi signori consoli dell'Arte della Lana, io Gabriello di messer Bartolomeo Panciatichi lanaiuolo mi richiamo di Giovanni e Michele di Benedetto da Carmignano di fiorini centoquarantadue di s. LxxVi a fiorini di buona moneta d'Ungheria che valgono rechati a moneta di Firenze per s. Lxxxi a fiorini [...] i quali denari me deono dare per resto di peze quatro e mezo di panni fiorentini e due coltri che vende de mia ragione in Sagabria d'Ungheria Maruccio di Pagolo Marucci di Firenze per me insino a dì xvi di giugno MCCCLXXXVII e però vi priegho mi facciate pagare e rendere le spese.' ASF, Arte della Lana 542 . fol. $28 \mathrm{v}$.

181 'Peze nove di drappi mandamo a chomune tra Bartolomeo di Lucha Rinieri e io a Buda [...]. ASF, Catasto 474. fol. 878r. 'Una ragione vecchia chomunico in sino l'anno 1410 in Ungheria [...] Una ragione nuova comunicai in Ungheria l'anno 1431 in achomanda in Antonio Popoleschi [...]'. Catasto 474. fol. 881r. 'Antonio di Aghinolfo Popoleschi di Buda de' avere fiorini ottanta cinque d'oro per le spese m'asegnia avere, fatte a drappi mandati a compagnia tra me e Bartolomeo Rinieri [...]'. ASF, Catasto 474. fol. 879r.

182 The local agent was Bernardo di Sandro Portinari. ASF, Catasto 482. fol. 371v. The earliest information on Gualterio di Sandro Portinari dates back to 1380 when he was mentioned in Zara (Zadar, HR) as a Venetian citizen. He traded with textiles and copper between Zara and Buda. His partners were Andrea di Ugo and Antonio di Santi, and he also became partners with Vieri de'Medici's company. In 1392, he was partner to Corso di Ricci and Jacobo da Prato. Teke, 'Firenzei kereskedőtársaságok', p. 132. The company was mentioned in Bernardo di Giovanni Portinari's declaration, submitted in 1433: ASF, Catasto 484. fol. $263 \mathrm{v}$.

183 Filippo as local manager of the Panciatichi firm in Buda: 'Filippo Capponi governatore della compagnia di Zanobi Panciatichi'. ASF, Mercanzia 7120. fol. 254v.

184 Giovanni Panciatichi married Caterina di Simone Capponi. ASF, Monte serie II. 2439. fol. 56v. (1420).

185 De Roover, The Rise and Decline of the Medici Bank, pp. 383-387. 
is clearly underlined by Giovanni's son, Zanobi's (1393-p. 1431), presence on Filippo Capponi's side in Buda. ${ }^{186}$ In 1427, Filippo was already of advanced age, and, by then, Zanobi might have acquired skills sufficient to take over the family business from his uncle.

Back then, as branch manager, Filippo owed Giovanni 9287 florins for his capital and profit. The declaration also mentions that the firm had huge outstanding credits of 36,398 florins in Buda, which they were unable to recuperate. ${ }^{187}$ Among their business clients were: Pippo Scolari, the Melanesi brothers, Currado Cardini, Leonardo and Giovanni di Nofri Bardi, and Filippo del Bene. ${ }^{188}$ The main profile of Giovanni's firm would have been textile trade. ${ }^{189}$ The Buda branch probably had such a good reputation that merchant families sent their sons to them for their apprenticeships. Among them, Biagio d'Antonio Spini, in 1429, and the Corsini brothers - Battista (b. c. 1408) and Matteo di Giovanni (b. c. 1406) - in 1431 spent some time at the Panciatichi firm to complete their training as international merchants. ${ }^{190}$ Filippo Capponi died in Buda sometime before 1433, probably leaving the direction of the branch to Zanobi. ${ }^{191}$

186 'Filipo di Simone Chapponi e Zanobi Panciatichi i quali per me dimorano in Buda [...]'. ASF, Catasto 79. fol. 13 or.

187 ASF, Catasto 53. fol. 1014r.

188 See the balance of the company, submitted in 1431. ASF, Catasto 381 . fols. $43 \mathrm{v}-44 \mathrm{v}$.

189 Among the luxury textiles sold by the company in Buda were 'velluto, turchino, chermusi, domaschino'. ASF, Catasto 381 . fol. $44 \mathrm{v}$.

190 '1429. Ricordo che questo dì 5 d'aprile io manciepai Matteo, Battista, miei figluoli [...] E questo dì detto di sopra andò Matteo sopradetto a stare a Buda d'Ungeria cola conpagnia di Giovanni Panciatichi e de'figluoli [...] E a dì detto andò Batista insieme col sopradetto Matteo per istare a Buda o dove a loro paresse ne'reame d'Ungeria con Simone e Tomaso di Melanesi.' Il Libro di Ricordanze dei Corsini, p. 131. Matteo di Giovanni Corsini is also mentioned in one of Antonio di Bonaccorso Strozzi's letters: 'Lo portatore di questa Matteo di Giovanni Chorsini, el quale viene tosta per suo facciende viene molto bene informato delle chondizioni e modi di questo reame, da llui saprai tutto [...].' ASF, CS ser. III. 131. fol. 22v. (10/05/1431) The young Matteo Corsini, while in Buda, even went into business with Francesco, son of Guido di messer Tommaso del Palagio, who, in the 1380 s, had already developed business interests in Hungary. 'Pretende aver avere certi denari fiorini da Francesco di ser Guido di messer Tommaso la quale è in Ungheria per cagone di certe faccende habiamo avere insieme in Ungheria.' ASF, Catasto 340. fol. 799r. Catasto 438. fol. 205v. Furthermore, Strozzi's letters also refered to Biagio Spini: 'Lo portatore di questa sarà Biagio d'Antonio de Spini ch'era qua per Panciatichi da llui sarete avisato [...]'. CS ser. III. 131. fol. 288r. (10/05/1429). Spini was among those Florentines who witnessed the payment to Masolino. In 1431, Biagio was probably away from Florence. Tripodi, Gli Spini, p. 153.

191 In 1433, Antonio di Giovanni Panictichi mentions him in his tax declaration. 'Filippo di Simone Chapponi stava in Ungheria fiorini 600 novi, facerò messi nulla perché è morto [...]'. ASF, Catasto 474. fol. 88ov. In 1428, he was still in Hungary when he figures in the testament of Miklós Perényi, master of the horse in the royal court. Arany, 'Firenzei kereskedők, bankárok és hivatalviselők'. 
The Fronte family might have also been closely connected to the Scolari by friendship ties, since Antonio di Pietro di Fronte was named as one of the executors of Matteo Scolari's testament. The Fronte was a small, new family in Florence, which probably traced its ancestry back only to Antonio's grandfather Fronte who lived sometime in the first part of the fourteenth century. As early as 1350, many notary documents refer to Antonio's father Piero di Fronte as a resident of the parish of San Pietro Scheraggio. ${ }^{192}$ In 1378 , Piero's household was the only one that shall be associated with Antonio's extended family. ${ }^{193}$ Piero was an active politician around the time of the consolidation of the Albizzi regime; his name as Standardbearer appears several times among the speakers in the meetings of the secret councils. ${ }^{194}$ Similarly, in 1433, only Antonio's nephew Antonio di Fronte di Piero di Fronte submitted a tax declaration. ${ }^{195}$ He declared 919 florins and 15 soldi of total assets, and he paid 16 soldi, 4 denari of catasto. The Fronte shared marriage ties with the Tosinghi, the Scolaris' neighbours in the Via Panzano, which might have helped them find their way into business in the Kingdom of Hungary. ${ }^{196}$

\section{Antonio (c. 1381-1426/1427) ${ }^{197}$ and Fronte di Piero di Fronte (c. 1380-c. 1418): The Business Brothers}

By 1392, Antonio had settled in Zara (Zadar, HR) and worked there for a couple of years as a representative of a Florentine firm. ${ }^{198}$ In 1406, after his sojourn in Dalmatia, his name appeared again in sources as the Florentine chancellery dispatched a letter of recommendation to Pippo Scolari on his

192 Michele di Jacopo da Rabatta acted as notary for the Fronte. ASF, NA vols. 14004, 14006, fols. 16v, 22r, 24v, 33r, 40r.

193 ASF, Prestanze 367. fol. 6v.

194 ASF, CP 14. fol. 19v (25/02/1376), 19. fol. 61v (14/og/1380); 21. fols. 86v (26/og/1382) 9or (o8/10/1382), $94 \mathrm{r}(15 / 10 / 1382), 95 \mathrm{v}(20 / 10 / 1382), 104 \mathrm{r}$ (07/11/1382), 118v (09/12/1382).

195 Antonio di Fronte di Piero di Fronte. ASF, Catasto 491 fol. 1ov. Ser Fronte di ser Tommaso di Fronte, Soldo di Fronte and Giovanni di Fronte di Giovanni probably did not belong to the same family. Catasto 492. fol. 2o6r, 495. fol. 465v, 492. fol. 268r.

196 Antonio di Piero di Fronte married Bindella di Bindo Tosinghi. ASF, Catasto. 27. fol. 248r. 197 Antonio's birth and death years are calculated based on the Tratte. Online Tratte of Office Holders, n. 10988. (1400), n.10991 (1402), n.10944. (1426), n. 10945 (1427). Fronte's possible birth year is calculated based on the Tratte. Online Tratte of Office Holders, n. 45971 (140o), n. 117541 (1401).

198 Teke, 'Firenzei kereskedőtársaságok', p. 211. n.9. 
behalf. ${ }^{199}$ His brother Fronte was first mentioned in the sources only in 1404, when the chancellery recommended him to Sigismund. ${ }^{200}$

The brothers appear frequently together in documents, which indicates that they went into business jointly whenever possible. ${ }^{201}$ It was customary in merchant families that brothers work together in business life and run their firms jointly. As we have already seen, similar patterns can be observed in the case of several Florentine families in Hungary: the Scolari, the Da Montebuoni, the Infangati, the Bardi, the Melanesi, the Lamberteschi, the Corsi, and the Cardini, which seemingly challenges Richard A. Goldthwaite's hypothesis that family relations had lost their importance in the management and organization of business partnerships. ${ }^{202}$

The Fronte brothers developed quite a varied business profile, which included participation in wool as well as in merchant companies. In 1406, Antonio was running a wool firm with Goso di Francesco di Goso ${ }^{203}$ and another wool firm he set up with Andrea del Palagio. ${ }^{204}$ In the early 1410s, Fronte was also involved in a third firm with Niccolò di Marco Benvenuti and Jacopo di Ubaldino Ardinghelli, which was trading in Hungary. ${ }^{205}$ Besides, in all these business interests, the Frontes' most important business partners were the Scolari and the Carnesecchi. Before 1411, Fronte founded a firm with Matteo Scolari and Antonio di Santi for trade in the Kingdom of Hungary. ${ }^{206}$ The close relations between them are also shown by the fact

199 ASF, Signori, Missive, I. Cancelleria 27. fol. 14v.

200 ASF, Signori, Missive, I. Cancelleria, 26.f ol. 51v. (11/07/1404) Not much later, Pippo received a similar recommendation in Fronte's name. ASF, Signori, Missive, I Cancelleria, 26. fol. 108v.

201 Antonio di Fronte wrote in his declaration, submitted in 1427: 'Diferenza chon Antonio di Piero di Fronte, mio zio, di più ragioni [...]'. ASF, Catasto 27. fol. 10ov. Antonio di Piero's declaration in the same year: 'Ho una diferenza con Antonio di Fronte, mio nipote [...]'. Catasto 27. fol. 117r. 202 Goldthwaite, 'La famiglia', pp. XXV-XXXIV.

203 ASF, Arte della Lana 25. fol. 3r, Arte della Lana 327. fol. 23 r.

204 Antonio di Fronte's declaration, submitted in 1431: ASF, Catasto 348. fol. 18r.

205 'D'avere dal signore re d'Ungheria per fatti di mio padre circha a fiorini vi milla in più partite di quali s'apartiene alle rede di Nicholò di Marcho Benvenuti e $3 / 8$ e alle rede di Jacopo Ardinghellli circha a fiorini cccc [...]'. ASF, Catasto 27. fol. 10ov. Jacopo Ardinghelli was relative to the Guadagni, since Nanna di Filippo di Neri Ardinghelli married Bernardo di Vieri Guadagni. ASF, Guadagni 12. docs. 4-5. See the declaration of Niccolò's son, Francesco in 1427, detailing his father's businesses in Hungary: 'Abbiamo una ragione pendente inchontesa chon Antonio di Piero di Fronte [...] Abbiamo alchuno credito nelle parti d'Ungheria e a Firenze, li quali pocha stima ne facciamo [...] Manonna l'omperatrice, donna dell'omperadore per $2 / 3$ toccha a noi, fiorini 40o. Lo imperadore d'Ungheria per $3 / 8$ toccha a noi fiorini 1800 [...]'. ASF, Catasto. 29. fol. $168 \mathrm{v}$.

206 Matteo Scolari left a certain amount of money by his last will for Fronte's heir. ASF Corp. Rel. Sopp. 78. 326. fols. 279v, 26ov. (1424) 
that Antonio di Piero Fronte received financial aid from Andrea Scolari to provide his daughter with a dowry. ${ }^{207}$

Maybe their friendship with the Scolari led them into politics as well. In the 1410s, Antonio participated as a speaker in the secret councils on a regular basis. ${ }^{208}$ However, in 1411 , he was not elected to a city office because of his absence from the city, which also suggests that at that time he was staying in Hungary. ${ }^{209}$ In 1412, the Florentine government commissioned him and Filippo Capponi to mediate between Ladislaus of Durazzo and Sigismund. ${ }^{210}$ Antonio was even captured during the Venetian wars and, in 1413, the Signoria thanked Sigismund for requesting his release. ${ }^{211}$ His service to the Florentine government resulted in Antonio's employment in the royal court. In the same year, Antonio urged the town court judges and the town council of Košice, Hungary, to provide the ruler with a new year's gift, an indicator of his employment in the royal administration. ${ }^{212}$ Sigismund surely appreciated Antonio's work to the extent that, in 1419, Antonio became royal familiaris and later was granted trade privileges. ${ }^{213}$ Fronte, through Simone Capponi, also obtained connections to the papal Curia, maybe as a collector or as someone closely related to the administration of papal revenues in Hungary. ${ }^{214}$ Fronte died sometime around 1418 , and it remained for his son, Antonio (b. c. 1406) to close his business.

The business settlement following Fronte's death included the dissolution of a merchant company he established in 1415 with Pagolo di Berto Carnesecchi (c. 1374-1427), in Buda. ${ }^{215}$ The Carnesecchi were close neighbours to the

207 'Ho a dare alle rede del vescovo di Varadino fiorini novanta denari, mi presto in sino quando maritai la mia figliuola.' ASF, Catasto 27. fol. 117r.

208 Between 1410 and 1426, he spoke 32 times at the secret councils, in the capacity of Twelve Goodmen and Eight of custody. ASF, CP 40. fols. 178v, 186v, 195r; CP 42. fols. 146v, 155r, 16ov, 168r; CP 43. fols. 5v, 6v, 10r, 18r, 24V, 25v, 39r, 137V, 143r; CP 44. fols. 113r, 115r, 125v, 141v, 164r; CP 45. fols. $37 \mathrm{v}, 45 \mathrm{v}, 71 \mathrm{r}, 101 \mathrm{v}, 106 \mathrm{r}$; CP 46 . fols. 10v, $48 \mathrm{v}, 154 \mathrm{r}, 158 \mathrm{v}, 187 \mathrm{v}$.

209 Online Tratte of Office Holders, n. 11018.

210 ASF, Signori, Missive, I. Cancelleria, 29. fol. 26r.

211 Zsigmondkori oklevéltár, IV. doc. 730.

212 Zsigmondkori oklevéltár, IV. doc.152.

213 Teke, 'Firenzei kereskedőtársaságok', pp. 195-196.

214 In 1418, Pope Martin V ordered the Archbishop of Esztergom to settle his debt with Fronte and Simone Capponi. XV. századi pápák oklevelei, I. doc. 54.

215 See Antonio's declaration, submitted in 1431. ASF, Catasto 348. fols. 18r-v. The date of Fronte's death is calculated based on the Online Tratte, as well as on the documents regarding his company with Ridolfo di Bonifazio Peruzzi. ASF, Mercanzia 271. None of the Fronte brothers lived until the end of our period, so only Fronte di Piero's son, Antonio, then 27 years old, presented a tax declaration. Catasto 445r. fols. 29v-3or. In 1427, the Carnesecchi brothers declared in their tax return that: 'Anchora troviano che dell'anno 1415 Pagholo, nostro padre fecie chonpagnia chon 
Scolari in Via Panzano, parish of Santa Maria Maggiore, gonfalon of Drago, quarter of San Giovanni. ${ }^{216}$ Their ancestry traces back to the beginnings of the fourteenth century, and by the end of that century they had established a name and a social status for themselves. In fact, Pagolo di Berto grew into one of the most active politicians of his time. ${ }^{217}$ His three sons, Simone, Piero, and Giovanni, followed their father's footsteps in business life and continued to cooperate with the Fronte in selling silk textiles in the Kingdom. ${ }^{218}$ The firm, which was reformed between the Fronte and Pagolo sons, operated with that organization at least until $1433 .{ }^{219}$ The Carnesecchi were involved in both wool and silk manufacturing in Florence; therefore, the joint company with the Fronte most likely sold their own products. ${ }^{220}$ The firm seemingly provided banking services, as well, and therefore became involved in the payments of the woodcarver-architect, Manetto Amannatini, and the painter, Masolino, on Pippo Scolari's behalf. ${ }^{221}$

Antonio di Piero di Fronte al traficho d'Ungheria, dove la resedenza di detta chonpagnia nella terra di Buda.' Catasto 55. fol. 789 r.

216 ASF, Monte ser. II. 1805. fol. 38v. (1405).

217 He was elected several times to consul of the Doctors' Guild. ASF, Arte dei Medici e Speziali 46. fols. 35V (1408), 39v (1416), 40v (1418), 41v (1420), 43v (1424), 44V (1426). Starting from 1395, he delivered at least 179 speeches. ASF, CP vols. 31-47.

218 See their joint declaration, submitted in 1427: ASF, Catasto 55. fols. 786r-792r.

219 ASF, Catasto 485. fol. 294r. In 1431, Pagolo's heirs prepared the balance of their father's old company, which he ran with Antonio di Piero di Fronte. 'Al nome di Dio a dì gennaio 1430. Apresso faremo nota a voi signori uficiali del chatasto del Comune di Firenze in che forma e stato si truova lla chonpagnia e traficho suto per l'adietro per Antonio di Piero di Fronte e per Pagholo di Berto Charnesechi nelle parti d'Ungheria e de parti di Firenze, che dipendono amendue da uno medesimo chorpo e per amendue le parti, ciòè per Simone e fratelli per la metà e per le redi d'Antonio di Piero di Fronte per l'altra metà.' Catasto 381. fol. 89r. Furthermore, see a business quarrel between Simone di Pagolo Carnesecchi's firm, which in 1426 was registered under the name of Antonio di Piero di Fronte, and the firm of Zanobi and Antonio di Giovanni Panciatichi of Buda. ASF, Mercanzia 7120. fol. 254r-v.

220 They previously had a company with Piero di Stefano di ser Piero and Francesco di Cionaccio Baroncelli, which sold and probably produced silk textiles. In 1427, in their declaration: 'Anchora ci troviano queste merchatantie chome apresso diremo la quale ci resta d'una chonpagnia suta fra Piero di Stefano di ser Piero e Francescho di Cionaccio Baroncegli e noi in prima; una pezza di velluto chermusi [...] una pezza di velluto nero [...] una pezza di velluto alesandrino [...] una pezza di marermatto tutto macchiato [...] una pezza di zetani raso nero [...] Anchora ci troviano dovere avere da Matteo del maestro Lucha setaiuolo per merchatantia avuta da noi [...]'. ASF, Catasto 55. fol. $789 \mathrm{v}$. In 1427, they were running a wool workshop in Florence, under Simone's name, with Giuntino di Guido di Giuntino. Catasto 55. fol. 79or. Before 1422, Antonio had shares in a silk workshop. Catasto 380 . fol. $46 \mathrm{v}$.

221 'Simone di Pagolo Carnesechi e fratelli deono dare per la ragione d'Ungheria fiorini 120 di ungheri fiorini 128 s. [...].' Declaration of Manetto's mother. ASF, Catasto 31. fol. 846r. Molho, 'The Brancacci Chapel', p. 93. 
In 1427, at the time of the general census in Florence, Antonio di Fronte was also sojourning in Hungary, and he was among the merchants recommended by the Florentine ambassadors to King Sigismund. ${ }^{222}$ While busy with closing his father's businesses, Giovanni di Pagolo Carnesecchi submitted the declaration in his name. ${ }^{223}$ We learn from the document that his uncle, Antonio di Piero, in founding the firm, invested 2500 Florentine florins as capital, which increased over the years, and in 1425 his investments reached 3876 Florentine florins. ${ }^{24}$ The major business profile of the firm was silk trade and it appears as an important buyer of the silk manufacturing companies run by Parente di Michele di ser Parente and Nofri di Giovanni di ser Parente. ${ }^{225}$ Their business clients included: King Sigismund, Pippo Scolari, Andrea Scolari, Tommaso Melanesi, Piero Guicciardini, Scolaio Tosinghi, Giovanni Falcucci, Filippo Capponi, Lorenzo da Montebuoni, Leonado and Giovanni di Nofri Bardi, Baldinaccio Infangati, and Piero Lamberteschi. ${ }^{226}$ At the beginning, the agent of the firm was Simone Melanesi, and later he was replaced by another young Florentine, Antonio di Bonaccorso Strozzi. ${ }^{227}$

In March 1426, Antonio di Bonaccorso Strozzi, back then an agent of the Carnesecchi-Fronte firm, was also present in Pippo Scolari's house as one of the witnesses of the document naming the executors of Matteo Scolari's testament. His lineage, the Strozzi, was of popolani origins, but their history

222 ASF, Signori, Legazioni e Commissarie, 7. fol. $76 \mathrm{v}$.

223 'Io Giovanni di Pagolo Charnesecchi opero redetta questa scritta di voluntà d'Antonio.' ASF, Catasto 27. fol. 116r.

224 'Feci una compagnia in sino l'anno 1415 con Pagolo di Berto Charnesecchi, e mise in chorpo di compagnia fiorini dumila cinquecento denari, cioè fiorini 2500 [...] e l'ultimo saldo faciemo de detta compagnia fu a dì primo di marzo 1424, nel quale mi trouai creditore di fiorini tremila ottocento settantasei s. xi d. 3 [...]'. Catasto 27. fol. 116v. See also Antonio di Fronte di Piero's tax declaration, submitted in 1431. Catasto 348. fol. 18r.

225 See Parente di Michele and Nofri di Giovanni Parenti's tax return, submitted in 1433: ASF, Catasto 485 . fol. 294r.

226 See the balance of the company: ASF, Catasto 381 . fols. 89 r-9or.

227 See the balance of the company, in 1427: 'Anotnio di Bonacorso degli Strozi nostro fattore in Buda [...]'. ASF, Catasto 28, fol. 1009. 'Antonio di Bonachorso fu nostro fattore de' dare, sono perduti in tutto stassi nelle parti d'Ungheria [...]'. Catasto 381. fol. 89r. (1431) Teke, 'Firenzei kereskedőtársaságok’, p. 196. 
goes back at least to the thirteenth century. ${ }^{228}$ By the beginning of the fourteenth century, they had already been conducting banking activity in the Kingdoms of England and France and had established one of the leading companies at the papal court. The lineage was one of the most extended in Florence at the time; in 1378 , they had 38 households. ${ }^{229}$ Since the early thirteenth century, they resided mainly in the parish of San Pancrazio, gonfalon of Leon Rosso, quarter of Santa Maria Novella. In 1433, the number of their households increased to 43 , comprising 220 family members. ${ }^{230}$ They declared as total assets 153,165 Florentine florins and paid 312 florins, 251 soldi, 126 denari of catasto. Among them, eight of the above mentioned families did not possess any taxable assets. ${ }^{231}$ If the Strozzi had any previous connections in Hungary or to the Scolari, it is unclear. Despite the well-researched studies on their history, there is very little known about Antonio's family. His father Bonaccorso di Pinaccio did not participate in politics, and there is no reference to any members of his nuclear family as speakers at the secret councils.

\section{Antonio di Bonaccorso Strozzi (b. c. 1398): The Commercial Agent}

Antonio, like several Florentines, including Simone Melanesi in Buda and Giovanni di Cenni Ugolini in Venice, initiated his own business activity by working first as an agent of local Florentine firms. In 1426, when Antonio was first mentioned in Buda, he must have been almost thirty years old. Therefore, he had been working as a merchant for quite some time. At that point, he was employed by the Carnesecchi-Fronte firm, and, in 1427, following its dissolution, he decided to stay. Around that date, he was also referred to as governor and factor of Antonio Popoleschi's firm in Buda. ${ }^{232}$ A year later, due to some unresolved issues between him and his former employers, Antonio complained in his letters addressed to his relative,

228 Goldthwaite, Private Wealth, pp. 31-32. Crabb, The Strozzi of Florence. Fabbri, Alleanza matrimoniale.

229 ASF, Prestanze 368, fols. 12r, 15v, 16r, 44r-v, 45r-v, 46v, 47r, 57r, 64v, 65v, 66r, 67r, 69v, 72r, $76 \mathrm{v}$. 230 ASF, Catasto 489. fols. 43or, 489r; Catasto 494. fols. 389v, 422r, 426r; Catasto 495, fols. 8v, 9r, 49r, 83v, 87r, 103r, 148r, 159r, 17or, 177v, 213r-v, 252v, 304v, 32or, 337v, 382r, 423r, 428v, 435r, 439r, $446 \mathrm{v}, 455 \mathrm{v}, 469 \mathrm{v}, 471 \mathrm{r}, 491 \mathrm{v}, 498 \mathrm{v}$; Catasto 496 . fols. 41r, 56v, 99v, 214r, 331r, 384v, 396v, 399r, 426r, $486 \mathrm{r}$.

231 ASF, Catasto 494. fol. 308r; Catasto 495. fols. 17or, 213r, 213v, 435r, 469v, 471r; Catasto 496. fol. 399r.

232 ASF, Mercanzia 7120. fol. 254v. 
Piero di Filippo Strozzi, that the Carnesecchi-Fronte firm still owed him 100 Florentine florins for his salary. ${ }^{233}$

While in Buda, he probably traded with the Strozzis' goods. ${ }^{234}$ In 1433 , he and his brother, Pinaccio, declared a joint wool workshop, which they kept in the Via dei Lanaiuoli. ${ }^{235}$ Furthermore, he operated another firm in Florence with Francesco di Simone Rucellai. ${ }^{236}$ He was also acquainted with the important members of the local Florentine community, among them, Leonardo di Nofri de' Bardi. ${ }^{237}$ His business partner in Buda was a certain Jacopo di Bartolomeo da Calenzano, a merchant who had been living in Hungary for a while. In 1427, Antonio even married Jacopo's sister, ensuring a further social bond between the two of them. ${ }^{238}$ Two years later, Jacopo, as many other Florentine businessmen, did not manage to avoid Sigismund's prison and was captured by the King's order. ${ }^{239}$ If Antonio followed him to prison, we do not know for sure, but his complete absence from later sources alludes to that possibility.

\section{The Peruzzi Family}

Ridolfo di Bonifazio Peruzzi figured among the guarantors of the commission carried out by the painter Masolino for Pippo Scolari. He was a descendant of the ancient lineage of the popolani Peruzzi, which, by the beginning of the fourteenth century, obtained a reputation in international business with its company agglomerate. ${ }^{240}$ In 1378 , the officers of the Estimo reported

233 'Attendo a voi quello avete fatto chon chetesti miei maestri sopra il mio salario [...] non fatte mancho di fiorini 100 d'oro la me chome mi fu promesso da Pagholo di Berto e Antonio di Piero di Fronte e voi ancho' lo sapete e simile Ghoro Serragli.' ASF, CS ser. III. 132. fols. 288r-v. (10/05/1429).

234 In 1429, he demanded silk and wool textiles from Matteo di Simone Strozzi for sale. ASF, CS ser. III. 132. fols. 287 r-v. (3/5/1429).

235 See Pinaccio's declaration submitted in their names, in 1433: ASF, Catasto 495. fols. 435r-436v. 236 Teke, 'Firenzei kereskedőtársaságok', p. 204.

237 Teke, 'Firenzei kereskedőtársaságok', p. 206.

238 See Antonio's letters sent from Buda to Matteo di Simone degli Strozzi, in Florence. (10/05/1431) ASF, CS ser. III. 131. fols. 22r-v. Jacopo da Calenzano settled in Buda, in 1417. He appears in Andrea Lamberteschi's declaration, presented in 1427. ASF, Catasto 27. fol. 94v. Antonio and Jacopo signed together a business letter, which was sent to Matteo di Simone Strozzi. ASF, CS ser. III. 132. fols. 289 r-v. (30/07/1429).

239 In 1431, Jacopo was listed among the debtors of Antonio di Piero di Fronte and Pagholo di Berto Carnesecchi in Hungary. 'Jachopo di Bartolomeo da Chalenzano in prigione e sono perduti fiorini 84 denari.' ASF, Catasto 381 . fol. 91r.

240 Hunt, The Medieval Super-Companies. Sapori, I libri di commercio dei Peruzzi. 
20 households of the lineage, which were located overwhelmingly in the gonfalon of Leon Nero, quarter of Santa Croce. ${ }^{241}$ By the end of our period, this number increased to 25 households, which had 119 registered family members. ${ }^{242}$ The entire lineage reported 67,171 florins of taxable assets and paid 125 florins, 119 soldi, and 68 denari of catasto. Of the total number of households, six - that is, almost one-quarter - did not have any taxable assets. ${ }^{243}$

In the fourteenth century, the Peruzzi was not only a leading merchant family, but its members had also become significant actors in domestic politics. In 1376, as one of the most active politicians of his time, Simone di Rinieri Peruzzi was dispatched to the Hungarian royal court in an official capacity. ${ }^{244}$ Consequently, his son Benedetto also stayed in the Kingdom for a while. ${ }^{245}$

\section{Ridolfo di Bonifazio Peruzzi (1370-1434/1436): The Entrepreneur}

It is not entirely clear, though, to what extent his relatives' connections in Hungary might have had an impact on Ridolfo's attempt to build business contacts there. Ridolfo, who was approximately the same age as the Scolari brothers, appears for the first time in Hungarian sources in 1409, as Fronte di Piero di Fronte's partner. ${ }^{246}$ The company lasted until 1418, the time of Fronte's death, when he and his son, Antonio, reformed it with Ridolfo's participation. ${ }^{247}$ The Frontes' financial resources were limited compared to other Florentine long-distance trade merchants, like the Panciatichi, so one might expect that Ridolfo made the major investments in the company. Fronte, who stayed permanently in Hungary, would have provided the work, which offered Ridolfo the freedom to travel only occasionally to the Kingdom. Besides his Hungarian businesses, Ridolfo was involved in several firms of various sorts in Florence, which suggests large-scale entrepreneurial activity. A partnership with Carlo di Piero Benizi was sometimes referred to as a bank

241 ASF, Prestanze 367. fols. 22v, 25r, 31r, 37v, 38r-v, 39r; Prestanze 369. fols. 98v, 12 or.

242 ASF, Catasto 492. fols. 15v, 43v, 72v, 77r, 83r, 105r, 123r, 126r, 130v, 147r-v, 186r, 201r, 206v, 267r, 313r, $387 \mathrm{r}, 403 \mathrm{r}, 430 \mathrm{v}, 439 \mathrm{r}, 446 \mathrm{v}, 451 \mathrm{r}, 467 \mathrm{v}, 476 \mathrm{v}, 522 \mathrm{v}$.

243 ASF, Catasto 492. fols. 77r, 123r, 147r, $387 \mathrm{r}$, $430 \mathrm{v}$.

244 See the Signoria's instructions to the ambassadors: ASF, Signori, Missive, I. Cancelleria 15. fols. 59 r, 61r.

245 'Dì 2 di giugnio 1379. Benedetto, mio figliuolo allora era a Padoa ovvero in Ungharia'. Sapori, I libri di commercio dei Peruzzi, p. 524.

246 He spoke for the first time at the secret councils in 1401. ASF, CP 35 . fol. 11r. (16/07/1401)

247 ASF, Mercanzia 271. fol. 25r. (1424). 
(banco) and other times as a warehouse (fondaco). ${ }^{248} \mathrm{He}$ also owned a wool workshop with Matteo di Forese Bizari. ${ }^{249} \mathrm{~A}$ third firm specialized in the wheat trade, which he established with Luigi Mannini and Giovanni di Jacopo dello Sciocco. ${ }^{25}$ His investments were so fruitful that in 1433 , he reported the highest total assets among the persons in this study, and in terms of absolute wealth, his household was ranked $29^{\text {th }}$ of the total number of households.

Ridolfo's life might have been like Bonaccorso di Neri Pitti's, who belonged to the inner circle of the regime. ${ }^{251}$ After entering politics in 1396, he decided to give up his commercial travels abroad and concentrate his energy on entrepreneurial activity in the cloth business as well as on domestic politics. Gene Brucker claims that Bonaccorso was regularly called to the palace for the meetings of the secret councils to advocate for the Signoria on foreign policy-making. However, a detailed analysis of the meetings shows that Bonaccorso spoke only occasionally at the special commissions, the Pratiche, and his name was registered only 43 times as a speaker during his political career, which made him far less active in politics than the majority of the Albizzi supporters studied in the present volume.

Ridolfo Peruzzi does not figure in Brucker's analysis among the most influential members of the Albizzi regime, despite the fact that his name appears as a speaker 177 times in the corresponding registers of the Consulte e pratiche. ${ }^{252}$ With this, he grew into one of the most active members of the faction, following speakers like Rinaldo degli Albizzi and Niccolò da Uzzano. He started his political career at the secret councils in 1401, but he engaged in frequent public speaking only from 1413 on. He also took part as a speaker several times in the meetings of the Pratiche, restricted to the inner circle of the regime. ${ }^{253}$ Ridolfo served multiple times as consul of the Merchant Court and Standardbearer of the urban militia, as well as deputy of the quarter of Santa Croce. In 1434, as one of the most vehement supporters of the regime, he and his family were exiled

248 ASF, Catasto 451. fol. 291r; Catasto 433. fol. 102v.

249 ASF, Catasto 451. fol. 301r; Catato 447. fol. 206r.

250 ASF, Catasto 450. fol. 486v.

251 Brucker established the inner circle of the regime mainly on the basis of participation in the pratiche. Brucker, The Civic World of Early Renaissance Florence, pp. 262-264.

252 ASF, CP vols. 34, 35, 37, 39-50.

253 ASF, CP 45. fol. 145r. (24/og/1423), CP 46. fol. 89r. (25/10/1425), CP 47. fol. 36 r. (o7/o1/1427), CP 47. fol. 62v. (o7/o8/1427), CP 47. fol. 63v. (23/og/1427), CP 48. fol. 63r. (24/o2/1429), CP 48. fol. $65^{\mathrm{r}}$ (19/03/1429), CP 49. fol. 127r. (24/02/1431), CP 49. fol.192r. (04/o9/1431), CP 49. fol. 192v. (05/og/1431), CP 49. fol. 215v. (16/o1/1432), CP 49. fol. 23or. (02/07/1432), CP 50. fol. 93v. (18/08/1433), CP 50. fol. 125r. (o9/o3/1434), CP 50. fol. 132v. (22/03/1434), CP 50. fol. 143v. (20/04/1434), CP 50. fol. $179 v$. (og/o8/1434). 
by Cosimo de'Medici. He died sometime before February 1436, when his heirs turned to the Merchant Court to settle the company balance with Antonio di Fronte. ${ }^{254}$

254 On 11 February 1436, the sons of Peruzzi and Antonio di Fronte di Piero brought the case to the Merchant Court in Florence. ASF, Mercanzia 271. fols. 11v-12v. On 14 February 1436, his heirs received an exemption from paying the fine at court. Mercanzia 271. fol. 13r. On 28 February 1436 , the sons of Ridolfo and Antonio di Fronte di Piero Fronte delivered the account books to the Florentine Merchant Court. Mercanzia 271. fol. 16r. On 19 March 1436, Ridolfo's heirs were trying to negotiate the debt at the Court. Mercanzia 271. fols. 24v, 31v. (27/3/1436), 78v, 120v-121r (16/11/1436), 140v (21/12/1436), 16ov-161r. (23/02/1437). 